\title{
Heritage and Patrimony of the Peasantry Framework and Rural Development Indicators in Rural Communities in Mexico ${ }^{1}$
}

\author{
Fabio Alberto Pachon Ariza², Wolfgang Bokelmann ${ }^{3}$ and \\ Cesar Adrian Ramirez Miranda ${ }^{4}$
}

\begin{abstract}
The analytical framework "heritage and patrimony of the peasantry" and its recommended implementation theoretically provide an enhancement over previous methodologies to examine rural development. The current paper measures rural development indicators in six Mexican rural territories, and analyses their interaction in the heritages and patrimonies of the peasantry. The principal indicators that affect the patrimonies in these regions were recognised as Pluriactivity, Social Acknowledgment, Biodiversity and Recycling. Based on these outcomes, the indicators that belong to the Human Patrimony define it as the lowest of all the heritages of the Mexican peasantry. The analysis of the results remarks on the fact that the emphasis of public policies on productive concerns has left out complicated social problems such as the loss of identity, diversity and culture. These matters are becoming the strongest threat affecting the Mexican peasantry to improve their quality of life while respecting their human rights.
\end{abstract}

Key-words: Rural development, wicked problems, quality of rural life.

Resumen: El marco analitico 'Patrimonios del Campesinado' y su implementación teóricamente proporciona un mejoramiento sobre previas metodologías que analizan el desarrollo rural. Este artículo presenta los resultados de la medición de los indicadores de desarrollo rural en seis regiones en México, además de analizar su interacción con los Patrimonios del Campesinado. Los principales indicadores que afectan los Patrimonios en éstas regiones fueron Pluriactividad, Reconocimiento Social, Biodiversidad, y Prácticas de Reciclaje. Basado en éstos resultados, los indicadores que pertenecen al Patrimonio Humano lo enmarcan como el más bajo de los Patrimonios del Campesinado Mexicano. El

1. Data de submissão: 3 de fevereiro de 2016. Data de aceite: 19 de fevereiro de 2017.

2. Universidad Nacional de Colombia. Departamento de Desarrollo Rural. Bogotá, Colombia. E-mail: fapachona@unal.edu.co

3. Humboldt Universität zu Berlin. Berlin, Brandenburgo, Deutschland. E-mail: w.bokelmann@agrar.hu-berlin.de

4. Universidad Autónoma de Chapingo. Chapingo, Estado de México. México. E-mail: cesarmr2001@yahoo.com.mx 
análisis de los resultados reconoce además el hecho de que las políticas públicas en este país tienen un fuerte sesgo en aspectos productivos, además de que han dejado de lado complejos problemas sociales como la pérdida de identidad, diversidad y cultura. Los anteriores aspectos se convierten en la principal amenaza para que el campesinado en México logre mejorar su calidad de vida y que se respeten sus derechos humanos.

Palabras clave: Desarrollo rural, problemas complejos, calidad de vida rural.

\section{Introduction}

Tackling rural development has been a complicated task for several reasons. For instance, rural development has been analysed taking into account disciplinarian points of view. Due to this segmented analysis, solving all the aspects that rural development involves has been problematic. As a possible consequence of that segmentation, comprehending rural development involves several approaches and perspectives. The stakeholders involved in those debates disagree on the best manners to tackle rural development challenges (KAY, 2005). On the other hand, historically the isolation of rural areas in many places determines their inhabitants to remain excluded from the decisions about their future (CHAMBERS, 1983).

The focus of the rural development analysis has mainly been from an economic point of view. The economic perspective puts productive activities first and privileges the forms to increase that production and hence the growth of the household incomes. Instead, other opinions regarding rural problems suggest the inclusion of social aspects and specifically the topic about the rights of the peasantry (DESMARAIS, 2008). Adding to the debate, the framework "heritage and patrimony of the peasantry" proposes that rural development should take two key points into consideration: the process to improve the quality of life for all rural inhabitants and the assurance that their rights are respected.

According to Pachón, Bokelmann and Ramirez (2016a), four general approaches have addressed rural development. The technocratic approach, focused on an economic analysis, highlights agricultural productivity. The Green Revolution is the flagship of this approach as the best manner to reach rural development. The sociological approach remarks on topics regarding the individuals that live in rural areas, instead of their economic activities. The socio-technocratic approach includes some social topics in the economic context of rural development. That is why the socio-technocratic approach remarks on competitiveness and diversification of rural incomes. The last approach is the political one, and Food Sovereignty leads the debate regarding the inclusion of the rights of rural inhabitants in the discussion.

In fact, the technocratic approach has strongly influenced both the academic debate and public policies around the world. However, the critics of this model argue that this disciplinary and unidimensional perspective just understands a complicated situation such as rural development based on economic growth, and leaves out the discussion about several topics. As a result, alternatives to the model focus on the ideas of 
a holistic analysis of the rural reality, taking into consideration the intangible characteristics of the peasantry such as traditions, culture, or social interactions that go beyond the economy, and remark on a systemic approach that takes people into account beyond their productive activities. Finally, they highlight the complexity of the rurality and its inhabitants. For instance, Boisier (2003) criticises the traditional development model as it confines the development to a linear process of 'trickling down effect' where finally the growth will include all people. Instead, he proposes a bottom-up process that starts in the base with real people based on real problems. Escobar (1998) unmakes the traditional idea of development and instead proposes several developments aimed at people who, finally, will decide the best way to reach their goals. De Sousa Santos and Meneses (2010) remark on the importance of Latin American countries to overcome the 'Colonial mentality' and construct their development ideas based on the power of ancient knowledge and traditions, recovering the ways of relating to nature and strengthening the values of their people.

The former method to address rural development based on the disciplines is being substituted nowadays by a transdisciplinary focus, which aims to involve as many perspectives as possible to construct new forms to analyse problems, and then find more innovative solutions. The theoretical framework "Heritages and Patrimonies of the Peasantry" is based on a transdisciplinary point of view. It integrates a way to assess the problems of rural areas into an organised structure, and hence, it privileges crucial aspects that the public policy should overcome.

This paper aims to examine the indicators of rural development based on the analytical framework 'Heritage and Patrimony of the Peasantry', looking for the establishment of possible relationships among these indicators. For this purpose, six different regions in Mexico were surveyed. The first analysis of rural development based on the analytical framework was done in Colombia (PACHÓN, BOKELMANN \& RAMIREZ, 2017), and the current paper uses the same methodology. This research is useful to evaluate the whole method, its indicators and its analytical framework, as a contribution to address rural development in a wide sense. The method becomes a practical alternative for the different stakeholders interested in rural development challenges, such as governments and policymaking staffs, peasants to identify real problems, or students and academics to approach rural development in a more holistic way.

\section{Methodology}

\subsection{Heritage and Patrimony of the Peasantry}

The Heritages and Patrimonies of the Peasantry analytical framework takes the most influential aspects of other approaches and perspectives and organises seven heritages and patrimonies that the peasantry holds for the purpose of improving their quality of life and ensuring that their rights are respected. In this context, it is important to discuss the meaning of heritage. According to Pachón, Bokelmann and Ramirez (2016b), heritage is a network of knowledge, traditions, views and practices that a society contemplates as vital for its history, identity and culture. Patrimonies are those structures, thoughts and behaviours that the society obtains from its ancestors. Based on these ideas, heritage and patrimony should be assumed in a similar way, and hence they should hold the relevance to be appreciated, protected, and promoted.

The analytical framework defines seven heritages: cultural, social, economic, natural, institutional, physical and human, described in Figure 1. However, in the debate, it is important to discuss the reason why the use of the idea of capital is avoided, which has been usually used. The common understanding of capital is its link to a market situation, associated with the sale of assets, goods or commodities for money. In such 
Figure 1. Description of the Heritages and Patrimonies of the Peasantry

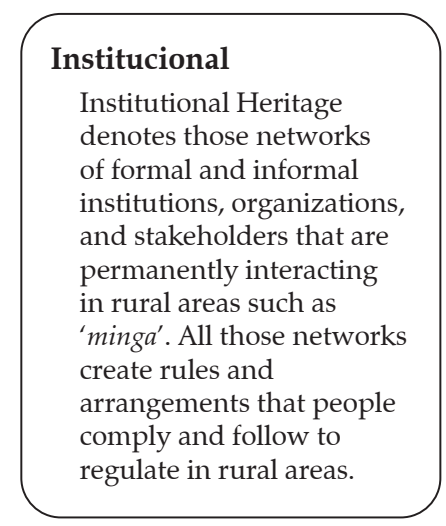

\begin{tabular}{|l|} 
Cultural \\
Cultural Heritage \\
takes into account those \\
aspects that belong to \\
the identity, creativity \\
and traditions of the \\
peas antry. Similarly, \\
other topics that \\
determine the practices \\
of peasants are the \\
spiritual and religious \\
beliefs. For instance, \\
traditions or rural \\
practices such as \\
polyculture and barter \\
systems. Additionally, \\
the Cultural Heritages \\
aim to identify how \\
modern agricultural \\
practices affect the \\
identity, beliefs, and \\
traditional practices \\
of the peasantry. \\
\end{tabular}

\section{Social}

Social Heritage refers to the integration, relationships, and interaction among the members of the society. In this case, the interaction between the peasantry and the urban society, as well as among peasants from different places and customs. Likewise, it also considers how these relationships can create confidence ties that strengthen peas ant organization.

\section{Heritages and patrimonies of the peasantry}

Economic
Economic Heritage
refers to monetary
resources. It is interested
in how rural
households earn incomes,
and how families spend
these incomes. Similarly,
Economic Heritage
monitors if the ways
to earn rural incomes
affect the environment,
or unfair situations such
as child lab our happen
in those activities.
It remarks in pluriactivity
of rural households,
as well as the
commercialisation
process.

Natural Heritage refers to biological resources.

For instance, water resources, landscapes, and biodiversity represented by animals, plants, and seeds. Equally, Natural Heritage takes into account the effects of agricultural practices on those resources, and the likelihood to recover traditional knowledge and ancestral production manners to conserve the biological resources and mitigate the effects of the climatic change.

\section{Natural}

\section{Human}

Human Heritage is the knowledge of the peasantry and rural communities. Equally, education networks, formal and informal, must be analysed as part of the way to transfer knowledge, abilities, skills, and forms to tackle the problems to new generations. Human Heritage identifies the manners to recover all that knowledge that has remained forgotten in the last time.

\section{Physical}

Physical Heritage essentially refers to access, availability, and likelihood to use adequate infrastructure in rural areas. Infrastructure is essential to reach rural development. For instance, the presence of health centers, schools, bridges, paved roads, irrigation water, and transport network in rural areas.

Likewise, Physical Heritage takes into consideration an adequate infrastructure in rural households, for instance, restrooms, clean water, or electricity.

Source: Own elaboration. 
scenario, traditions, culture, identity, ancestral knowledge or behaviours described as capitals, are placed in a commercial world. Nevertheless, heritage and patrimony become invaluable and uncommercial. For instance, the peasant identity is not a capital and hence it is impossible to exchange it for money (PACHÓN et al., 2016b).

\subsection{Selection of indicators}

Pachón, Bokelmann and Ramirez (2015) explain the methodology to choose the indicators to evaluate rural development in a comprehensive manner. 23 rural development indicators were selected using different tools such as the Vester's Matrix, a panel of experts, an online survey and a statistical analysis using the Principal Component Analysis. These indicators were organized into the analytical framework "Heritages and Patrimonies of the Peasantry" (Figure 2). Some indicators such as Biodiversity, Female
Participation, Security, Fundamental Rights or Social Acknowledgment belong to more than one patrimony because their spheres influence the scope of those patrimonies.

Annex 1 shows the indicators selected, as well as the questions that addressed key factors narrowly related to the 'Heritages and Patrimonies of the Peasantry' framework. Each issue was classified into three levels: Low (1), Medium (2) or High (3) according to the answers of every interviewed. The level of the indicators was pondered according to the responses of the questions that belong to them. Consequently, the level of the indicators could be Low (1.0-1.66), Medium (1.67-2.32) or High (2.33-3.0).

Accordingly, the level of the Heritages is the result of the mean of the indicators that belong to every Heritage. For example, the level of the Physical Heritage is the outcome of the mean of Incomes, Entrepreneurism, and Infrastructure. Equally, the levels could achieve a Low (1.0-1.66), Medium (1.67-2.32) or High (2.33-3.0) rank.

Figure 2. Indicators of the Heritages and Patrimonies of the Peasantry
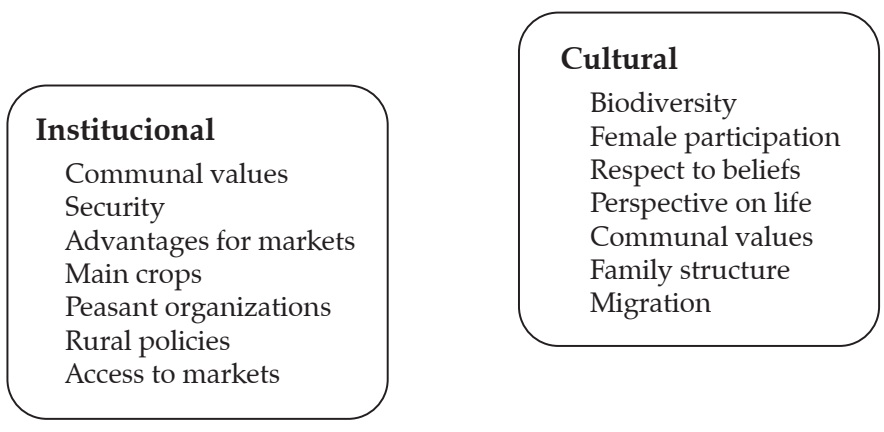

Heritages and patrimonies of the peasantry
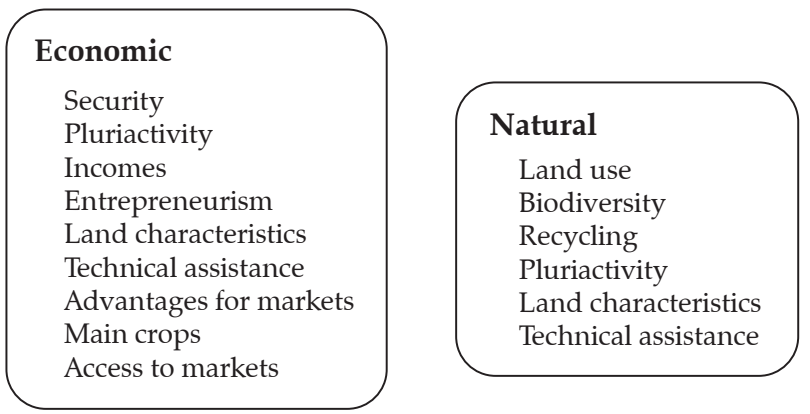

\section{Social}

Female participation Social acknowledgment Respect to beliefs Fundamental rights Peasant organizations Family structure Migration

Source: Own elaboration. 


\subsection{Selection of regions to apply the tool}

Six different regions from three different Mexican states were chosen to apply the tool (Figure 3). These regions were randomly selected from the places where the Programme of technical assistance has presence, and hence agricultural activities were an important way of their inhabitants to get their livelihood. 193 faceto-face interviews were done. In the Michoacan state, 31 surveys were done in Uruapan, where avocado production is the main activity, and 31 surveys in Etucuaro, characterised by mezcal production. In the Oaxaca State, 37 surveys were done in the city of Zimatlan. Finally, in the Mexico State, 31 interviews were performed in Teotihuacan close to the archaeological site, 33 interviews were done in Tejupilco, while 30 were done in Temascaltepec.

Figure 3. Regions selected in Mexico

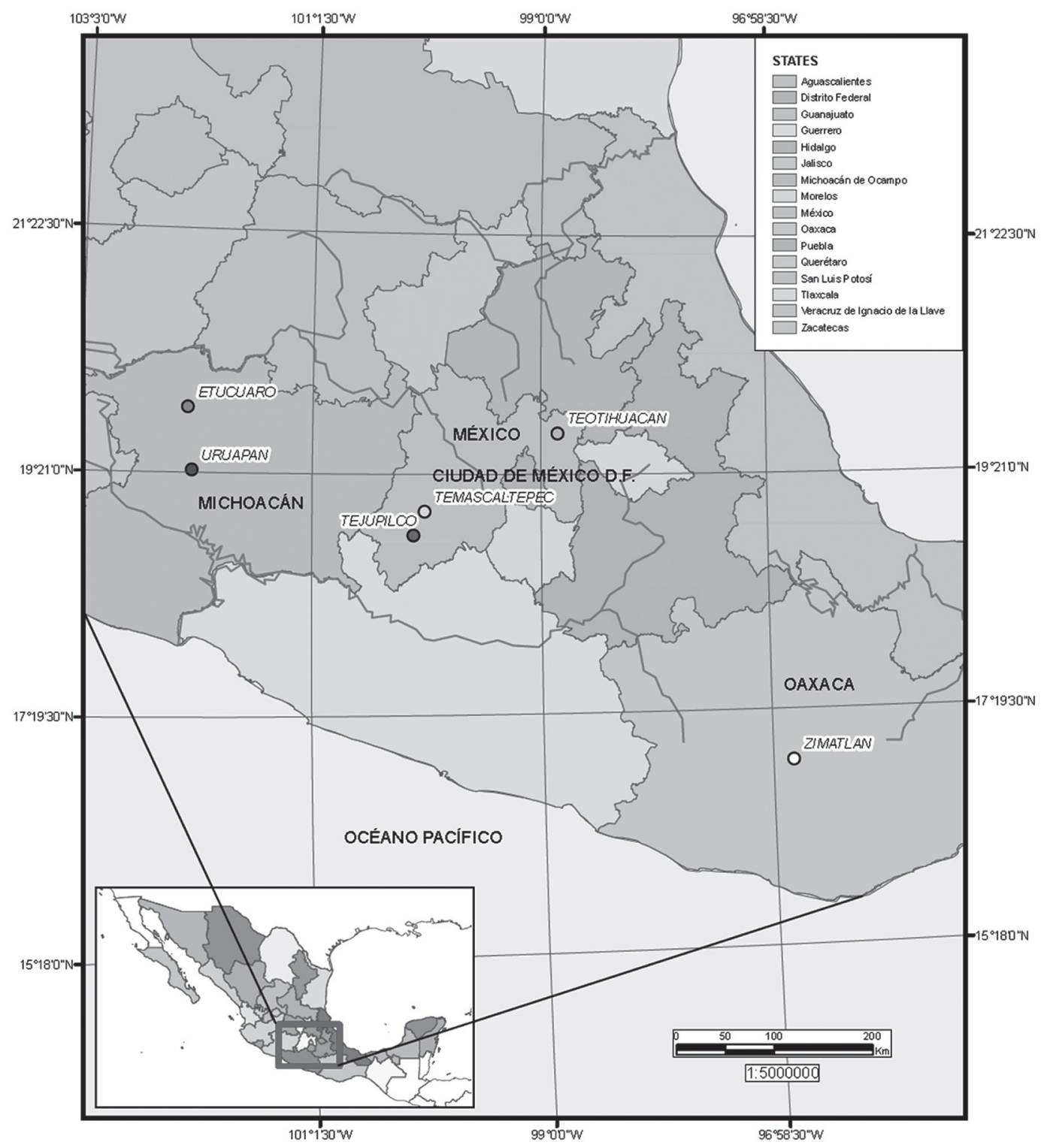

Source: Own elaboration. 


\section{Results and discussion}

\subsection{Teotihuacan}

The area where the data were gathered is close to the Teotihuacan Archaeological Site. That site is visited by more than two million of people every year, which means the peasants who live nearby are strongly influenced by tourism. The positive impact of tourism is evident in the excellent infrastructure available, but it has also had an adverse effect because is the hotel industry managed mainly by foreign investors the one that is obtaining the highest economic revenue. Ely (2013) describes that tourism in many cases has generated a loss of identity, displacement of local cultures by foreign ones, and increases in alcoholism, domestic violence, delinquency and prostitution. However, the same author argues that the kind of tourism in Teotihuacan looks for a 'cultural' experience and shows respect for the place. It is precisely in this scenario where the peasants interviewed are in the process to recover traditional cacti crops such as maguey, nopal, or agave.

Figure 4 shows the results of the indicators measured and their influence over the
Patrimonies of the peasantry they belong to. It is remarkable that most of the indicators got a high level, with some exceptions such as Biodiversity and Social Acknowledgment.

Ciudad de Mexico is $50 \mathrm{~km}$ away from Teotihuacan, which is why its influence is evident. Such influence impacts the indicator Migration that reached a medium level because most of the young people are moving there looking for jobs. On the other hand, the indicator Perspective on Life got a medium level because the peasants do not have the habit of resting. They perceive the future of the countryside as tough due to economic and environmental problems, and especially because they describe that their rural community has serious problems with alcohol consumption.

The Economic Heritage reached a high level, especially because the archaeological site becomes an excellent opportunity to get incomes. Even though the Migration indicator belongs to this heritage, its influence is low because the other indicators such as Access to Markets, Advantages for Markets and Technical Assistance got a high level. The peasants interviewed argued that they have an excellent place to commercialise their products. That is why they have even started

Figure 4. Results of Teotihuacan

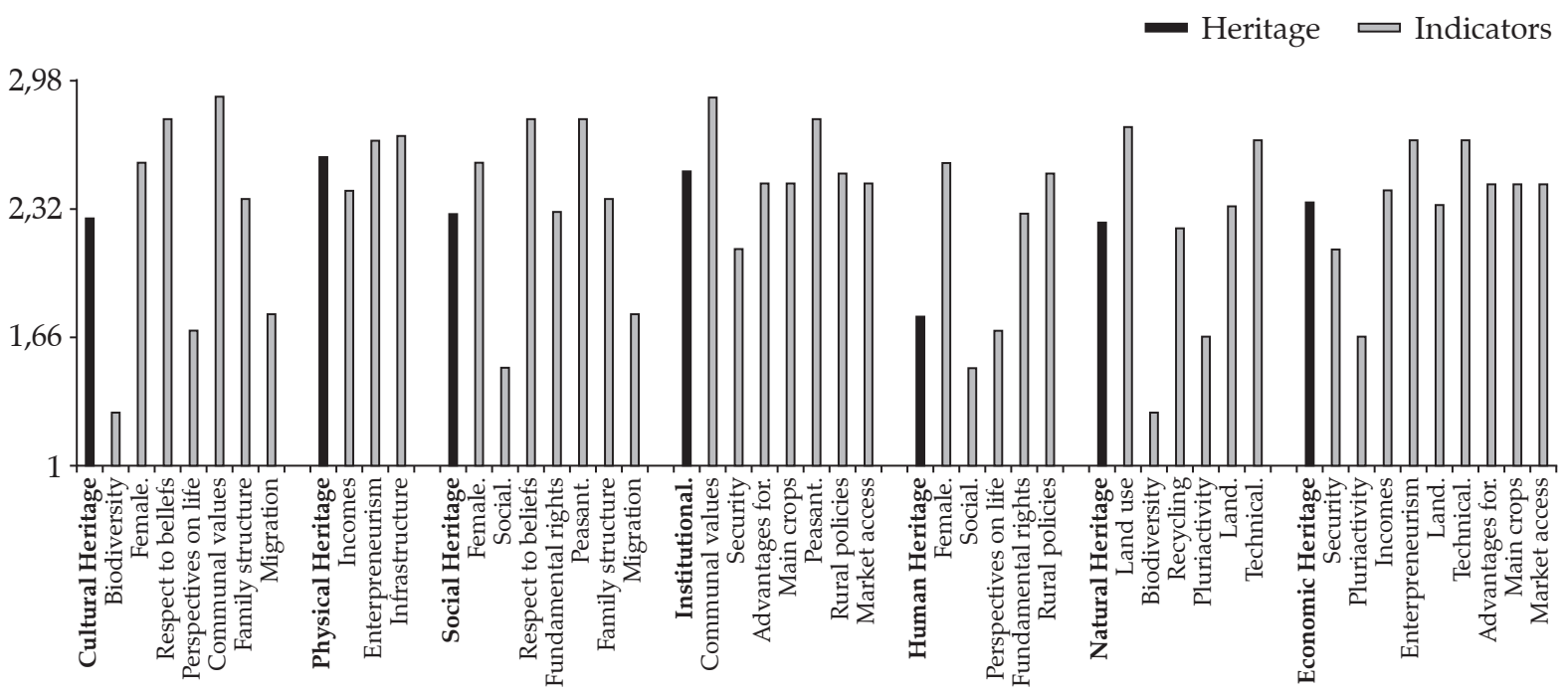

Source: Own elaboration. 
new enterprises linked to cactus crops such as agave, nopal and maguey, particularly to produce pulque. Pulque is an alcoholic beverage elaborated from the fermentation of the maguey. In ancient ages, pulque was considered as a sacred beverage.

In the case of the Cultural Heritage, almost all its indicators are at a high level. For instance, Female Participation, Respect to Beliefs or Communal Values. In contrast, Migration and Biodiversity got at a low level. Two facts call the attention in the Biodiversity indicator. On the one hand, while they argue that many animal species have been lost due to the urban expansion and the drying process of Lake Texcoco, some of the peasants point out that they have recovered many cactus species such as nopal (Opuntia vulgaris), maguey (Agave americana L), biznaga (Echinocactus) or thistle (Silybum marianum) as an alternative to generating incomes.

Another interesting fact is that the peasants are recovering a traditional custom along with those plants, which is the production and consumption of the ancient beverage called pulque. Those agave species have a high value because have been used to avoid soil erosion and to obtain the agave sap, which fermented, produces pulque. People have consumed it in Mexico since ancient times. However, at the beginning of the second decade of the last century, the government released a new sanitary legislation and a tax regulation for the production of pulque, which coincides with the formation of a new beer industry, that weakened the trade of this alcoholic beverage and transformed its social value (MONTES, 2014).

Natural Heritage was between a medium and a high level because its indicators Land Use, Technical Assistance, Recycling and Land Characteristics got a high level. However, Biodiversity got a low level. On the contrary, Human Heritage is the lowest patrimony in Teotihuacan. A topic associated with such level is the domestic violence pointed out in the Female Participation indicator. The interviewed argued that this problem is recurrent in rural areas and it is mainly related to alcohol consumption, which is confirmed by a study conducted by
Jaen, Aragón, Amorin and Rivera (2015), who identified that one out of three cases of domestic violence in the Mexico State was associated with alcohol consumption by the male partner. Then, this is an example of a situation with two sides where the traditions of ancient production are recovered, but at the same time, they could generate adverse consequences for rural families. Other indicators related to Human Heritage show the perception of peasants regarding the equity of rural areas. They debated about the fact that nowadays the rural society is more inequitable than before because poverty has been rising. Equally, peasants discussed regarding the fact that in rural areas the resting habits are not usual, and they work even on Sundays.

The proximity to the archaeological site and significant urban areas determined that the Institutional, Social and Physical Heritages got a high level. For example, they enjoy great governmental offers such as infrastructure and universities, schools and health centres in the nearby. However, such proximity undoubtedly facilitates the migration of young people and affects the indicator Pluriactivity because most of the people, men and women, that remain in the countryside are currently working full time off the farms, leaving the agricultural activities to their parents.

\subsection{Etucuaro}

The region of Etucuaro in the state of Michoacan is featured by mezcal production, a distillate of the agave, which becomes the base of its economy. Recently the region has suffered problems associated with violence. However, most of its indicators of rural development got a high level, but Recycling and Pluriactivity reached a low level. The first one, because adequate disposal practices are infrequent among Etucuaro's peasants, and Pluriactivity because most of the people are working full time off the farms. Figure 5 shows the results of all the indicators of rural development and the Heritages and Patrimonies in Etucuaro. 
Figure 5. Results of Etucuaro

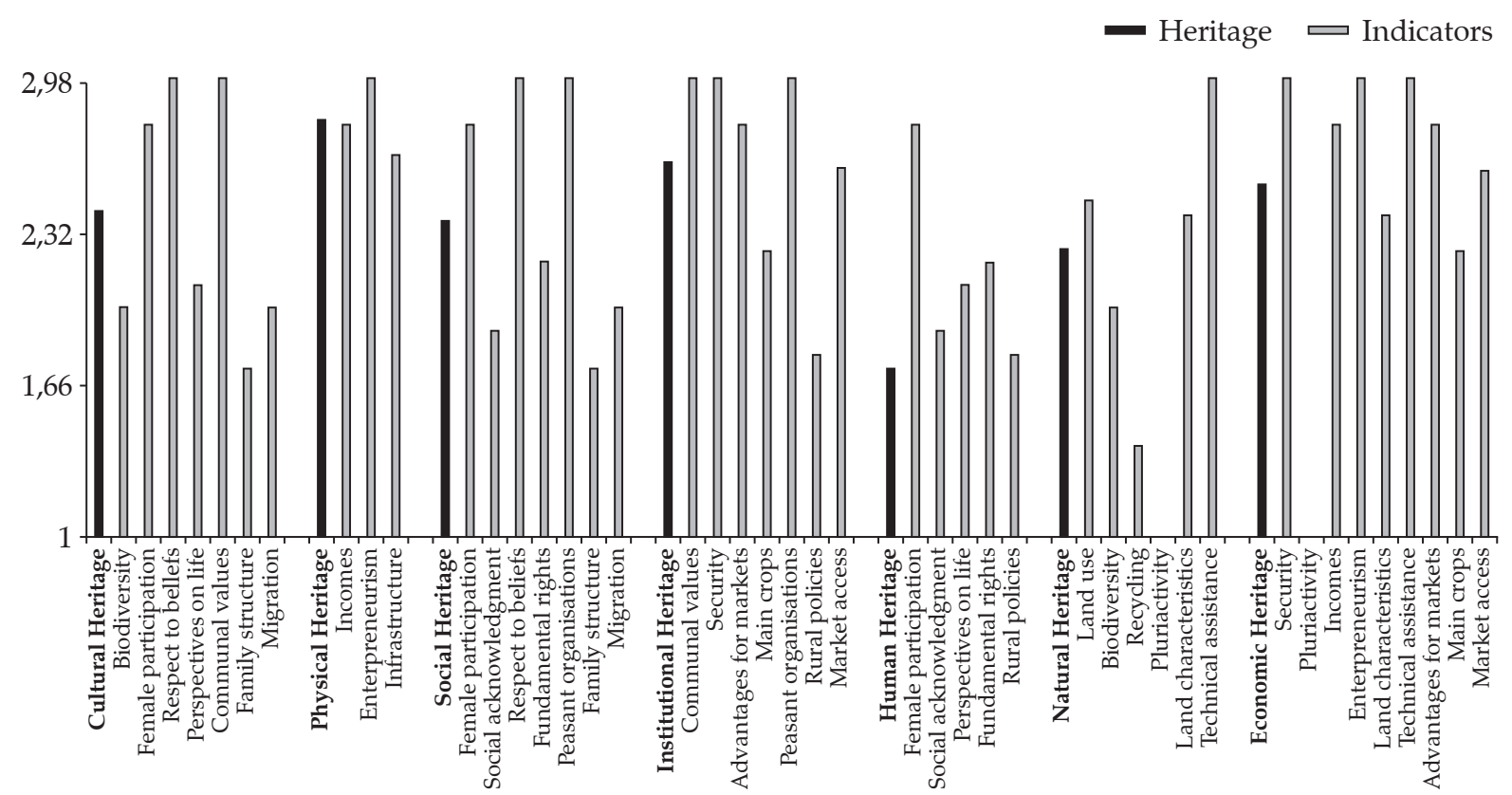

Source: Own elaboration.

The Heritages of Etucuaro's Peasantry reached a high level, except the Human Patrimony, which reached a medium level. The production of mezcal is one of the main reasons why most of the indicators got a medium to high level, and it reflects the positive influence of recovering traditional practices such as the distillation of agave.

The Social Heritage got a high level with a medium tendency. The indicator Social Acknowledgement was at a medium level, because according to the interviewed, for young people in the neighbourhood to be a peasant is trifling and even a shame. Equally, Migration was described as a significant challenge because in all families at least one of their members has migrated to the United States. However, the indicator got a medium level because hand labour is still available in the area. Regarding the indicator Fundamental Rights, the peasants declare that access to culture is a challenge because the cultural offer in the nearby is scarce. Another concern of this indicator was the access to an old age pension. Even though the Mexican government holds subsidies to old people in rural areas, this was described as another problem by the interviewed because there are many old people in the countryside unable to work and to obtain their livelihood. Regarding the access to education, it was common to find out that the goal of young people is to migrate, instead of attending school. That is why the level of education was not high, and some people remain illiterate.

The Institutional Heritage reached a high level and Security was an indicator remarked by the interviewed as relevant. Even though the Michoacan State has suffered violence problems because of the presence of organised crime groups (DÍAZ \& PÉREZ, 2015), the strategy of self-defence was assessed as successful by the interviewed. However, it is important to mention that a similar strategy was carried out in Colombia against rebel groups, but the main result was an exacerbation of the rural violence (CASTRO, 2014).

Human Heritage was the lowest patrimony in Etucuaro. Besides migration and Perspectives on Life, the indicator Rural Policies got a low level. 
This indicator was assessed low because the interviewed argue that they do not have any governmental support. However, it is important to mention that the Mexican government has a set of programmes to support the farmers in all the country, and obviously, Etucuaro receives that help. Regarding the indicator Perspective on Life, the peasants answered that they do not have resting habits and because they do not have an offer of other recreational activities, the only possibility of entertainment is alcohol consumption.

The Natural Heritage was between a medium and a high level. The indicator Recycling was the lowest because the interviewed responded that they did not have any practice of disposal of reusable materials. On the contrary, most of them burn them. Biodiversity got a medium level because peasants overcame the times when planting agave and producing mezcal was forbidden, a fact that allowed the region to recover its ancient culture. As it was described for pulque, producing mezcal was prohibited for many years. However, nowadays it is the basis of the regional incomes, and the organisation to produce it has been strengthened by a protected designation of origin (SILVA \& GARCÍA, 2015). Growing agave again facilitates the survival of the whitetail deer (Odocoileus virginianus), whose population had suffered a significant decrease in this area due to agave is an important component of its diet (FULBRIGHT \& ORTEGA-SANTOS, 2007).

The Economic, Cultural and Physical Heritages reached a high level. Even though Pluriactivity reached a low level as a consequence of migration, it is important to note that rural enterprises to produce and commercialise mezcal are becoming strong in the region. As it has been remarked, the mezcal distillation and commerce have, in general, positive effects on several aspects of the economic, cultural and physical heritages. However, some challenges associated with it such as alcohol consumption still remain.

\subsection{Uruapan}

Uruapan is located in the State of Michoacan, and it is featured as the region with the highest avocado production in the world (MARTÍNEZ, BONALES, ZAMUDIO \& GAYTAN, 2011). The economy of Uruapan is mainly influenced by this crop, which means that all the value chain, the planting, transportation, agricultural supplies, commercialisation, and the like, have benefited economically from avocado. Figure 6 shows the level reached by the indicators of rural development and the Patrimonies of the peasantry in Uruapan.

As it was described previously, Michoacan has been affected by violent conflicts and Uruapan is not the exception. According to Aranda (2013), organized crime has taken over some avocado and blackberry farms to legalise money from drug trafficking, which evidence firstly, the incapacity of the Mexican government and its institutions to provide security to the people from Uruapan and to control these organizations, Secondly, the immense capacity of these organizations to cover all the spaces in the society to laundry their income, and finally, the stigma that falls on those who directly or indirectly work with this crop of being related to illegal activities. 
Figure 6. Results of Uruapan

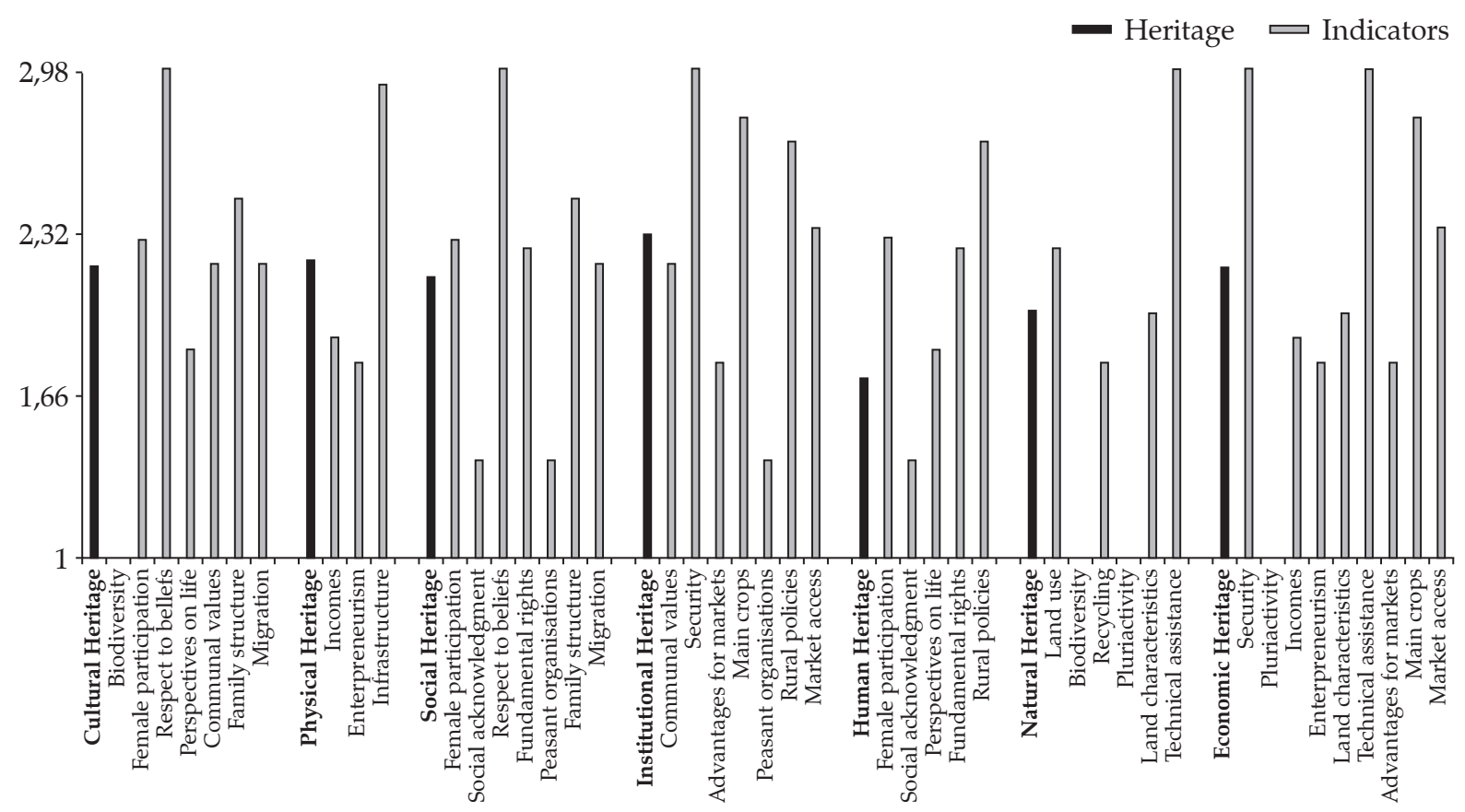

Source: Own elaboration.

Some indicators such as Biodiversity, Social Acknowledgement, Peasant Organisations and Pluriactivity got a low level. According to the interviewed, Biodiversity is severely impacted because of the process of losing forests to expand avocado crops, and similarly because of the intensive use of agrochemicals to avoid phytosanitary problems in the avocado monoculture. Equally, the Pluriactivity has been affected as well by the avocado crop because the pressure for the land has increased and hence, agriculture enterprises have been grabbing it to establish new plantations. As a consequence, peasants have had to sell their land, and look for work off the farms.

It calls the attention that even though the avocado production is strongly profitable, none of the Heritages of the Peasantry in the region got a high level. The interaction of the indicators that belong to the Institutional Heritage determined its highest level. However, the indicator Communal Values, which in other regions got a high level, in Uruapan reached a medium because one of the most important features of the peasantry, solidarity among neighbours, has been lost according to the interviewed. They argue that nowadays farmers in the region prefer to work alone in order to avoid problems such as those described previously. Regarding the Advantages to Markets, the level was medium because avocado regularly has high prices, then the peasants do not need to look for new alternatives such as organic or post-harvest practices, which should be a characteristic of the peasantry to access to new markets. Precisely, concerning the Market Access, almost all the production is exported to the United States, and just the second quality avocado is commercialised in the Mexican market. From the economic point of view, it is a desirable situation. Nevertheless, from the point of view of our analysis the local and national market should be privileged for the purpose of consolidating the food sovereignty of the Mexican people.

The Human Heritage is the lowest in Uruapan, similarly to all the regions interviewed. Its indicators, such as Social Acknowledgment, got 
a low level mainly because, according to the interviewed, young people do not feel proud of agricultural activities, and they want to migrate, especially to the United States. Regarding the indicator Perspectives on Life, the level was medium due to basically the same reasons than in other regions: the resting habits of peasants and the alcohol consumption. On the other hand, the indicator Fundamental Rights is affected by the access to an old age pension.

Natural Heritage, which got a medium level, is perhaps the most impacted by avocado crops. The indicator Land Use is affected because an area that could be used for diverse crops to supply Mexican people is currently used for a monoculture targeting international markets. Similarly, from the point of view of the Natural Heritage, the indicator Biodiversity is the most disturbed because the tradition of the Mexican Peasantry of growing the 'Milpa' has been lost in Uruapan. Milpa is a tradition to grow beans, pumpkin and maize together, which constitute the base of the Mexican diet. The peasants answered that the tradition has been lost because the regulation of The United States has forbidden growing other plants associated to avocado for export. Equally, the indicator Land Characteristics got a medium level because nowadays the use of agrochemicals to control phytosanitary problems has risen, and environmental problems have been reported as a consequence of it (VILLASEÑOR, 2005).

The Cultural, Physical, Social and Economic Heritages reached a medium level with a high tendency. The results got by the indicators of the Economic Heritage call the attention. For instance, the indicator Incomes got a medium level because the peasants answered that they have asked for many loans because the establishment of crops is extremely expensive, the time to reach the high production is long and they need incomes meanwhile. Instead, they use much of the incomes to pay those loans and buy agricultural supplies and the money to save is little. Regarding the way to spend money, several of the interviewed answered that men are the ones who make the decisions about how to do it, which means that the rest of the family is left out of these choices or their opinions are ignored. The indicator Entrepreneurism was low because peasants do not look for other options to use the farms, again for the profitability of the crop. Finally, they remark that the Access to Markets has been difficult. A recurrent answer among peasants was the problems with the middlemen, who gather the avocado and do not pay the production immediately, which is usually done two months later. In some cases peasants have even described situations in which the middlemen have not paid the production at all. Concerning the economic benefits of the avocado crop in Uruapan, Huacuja (2008) analyses the value chain and concludes that six multinational firms concentrate the higher share of the crop profits, and emphasises on the sustainability in of this value chain the middle term, especially because of the environmental and social impact of the crop, as it has been pointed out by the current research.

\subsection{Zimatlan}

Zimatlan is a town near the capital city of the Oaxaca State, located in Southwestern Mexico. The economy of the region interviewed is based on horticulture and sporadically small livestock farming. The data were collected in an area slightly isolated in comparison with the others regions interviewed. The area is characterised by unpaved roads and a lack of an appropriate transport network, even though is it located just 40 minutes from the town centre.

Figure 7 shows the level reached by the indicators and their impact over the patrimonies of the peasantry in Zimatlan. As in other regions, the indicators Biodiversity, Social Acknowledgment, Pluriactivity and Advantages for Markets got a low level. The last indicator refers especially to a tendency to produce basic agricultural goods, without adding any value or specialisation in organic production. 
Figure 7. Results of Zimatlan

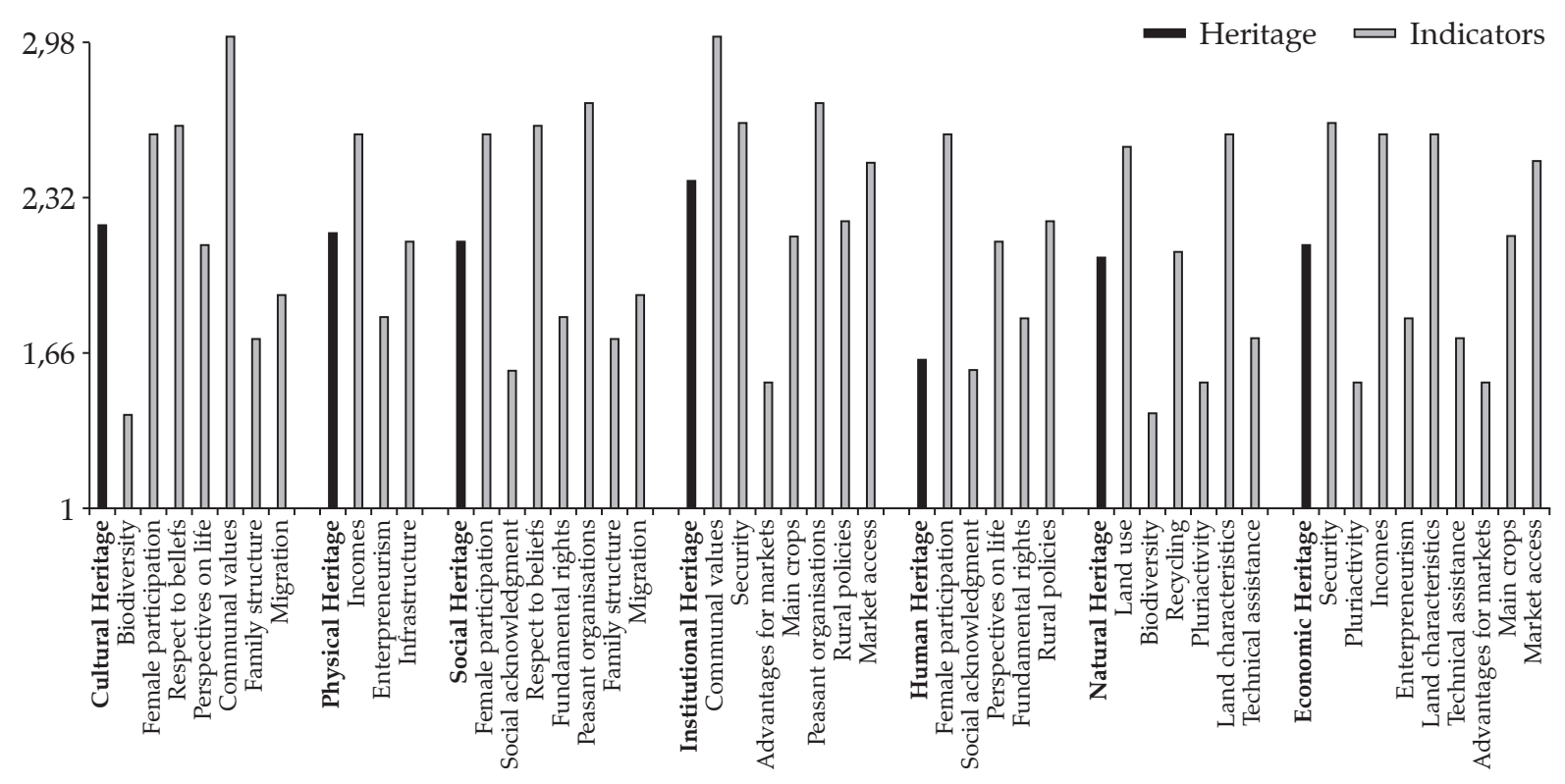

Source: Own elaboration.

Similarly to the other regions, the Human Heritage reached a low level. The reasons for this level are similar to the ones in the other regions: the interactions of topics described previously such as domestic violence, the tendency to migrate of young people and the problems to access to education in rural areas, especially basic education. Regarding the education matters, it is important to remark that, even though in Zimatlan it is possible to attend a university specialised in agricultural topics, the primary and secondary education in the interviewed area is challenging because of its isolation. Nevertheless, an alternative is applied in the countryside in Mexico, which is the tele-secondary school. According to Aguirre (2015), more than one million adolescents in semi-urban and rural areas in Mexico attend the tele-secondary. In simple words, it is an educative alternative for isolated areas based on the use of television technology to offer formal education. A teacher is responsible for answering the questions after the television classes, as well as to guide the fulfilment of the learning tutorials. Even though there are several criticisms of the model, because it offers less than necessary to children who need more, it is a fact that the tele-secondary is an alternative to provide education to children that in other circumstances will drop out formal education. Indeed, in terms of knowledge and social interactions with teachers and partners, regular training shows several advantages, but it is an option to prevent people from remaining illiterate (REYES, 2014).

The Cultural, Economic and Social Heritages reached a medium level. Similarly to other regions, Natural Heritage got a medium level. Nevertheless, in the current case, it is on the border with the low level. Besides the topics remarked in the other regions, the indicator Technical Assistance was highlighted by the interviewed. They argue that the quality and pertinence of the assistance could be better, and call the attention to the fact that the university in Zimatlan focuses precisely on agricultural topics, which is an opportunity to improve this concern. On the contrary, the interaction of the indicators related to Institutional Heritage accommodated it at a high level. It calls the attention that the indicator Advantages for Markets reached a low level, which could be explained by the fact described below. 
The Physical Heritage got the lowest level of all the regions. The area where the data were gathered is isolated, and on the contrary to other regions, the main characteristic was that the roads were unpaved. According to the Secretaría de Infraestructura de Mexico (2016), the tertiary ways that communicate the countryside hold more than $200.000 \mathrm{~km}$ of unpaved roads, useable especially in the dry periods, and well maintained during the rainy seasons. However, it is important to remark that Mexico holds an excellent infrastructure in comparison with other Latin American countries, especially in relation to highways (WORLD BANK, 2016). Regarding this problem, the interviewed remarked the fact that, although the roads are usable almost all the time, during the rainy seasons they remain isolated because the 'Seco' river does not allow the transit by car, motorcycle or even by animals such as horses or donkeys. They requested urgently the construction of a bridge over the river because, for example, the children cannot attend school during those seasons.

\subsection{Tejupilco}

Tejupilco is a city located in the Southwest of the state of Mexico. It is located in an area where the agricultural activities are the most relevant economic activity. The results of the indicators and the Heritages of the Peasantry in Tejupilco are similar to the other regions (Figure 8). Biodiversity, Recycling, Pluriactivity and Advantages for Markets got a low level. On the contrary, the indicator Family Structure got the lowest level in comparison to the other places interviewed.

Physical Heritage reached a high level, but in contrast to the other regions, Institutional Heritage got a medium level. The Economic, Cultural and Social Heritages were at a medium level with a high tendency. In the case of Tejupilco, the Natural Heritage got a medium level for the same reasons discussed previously.

Human Heritage reached a medium level with a tendency to a low one, and it is interesting to discuss the level got by the indicator Perspective on life, and specifically in the matter

Figure 8. Results of Tejupilco

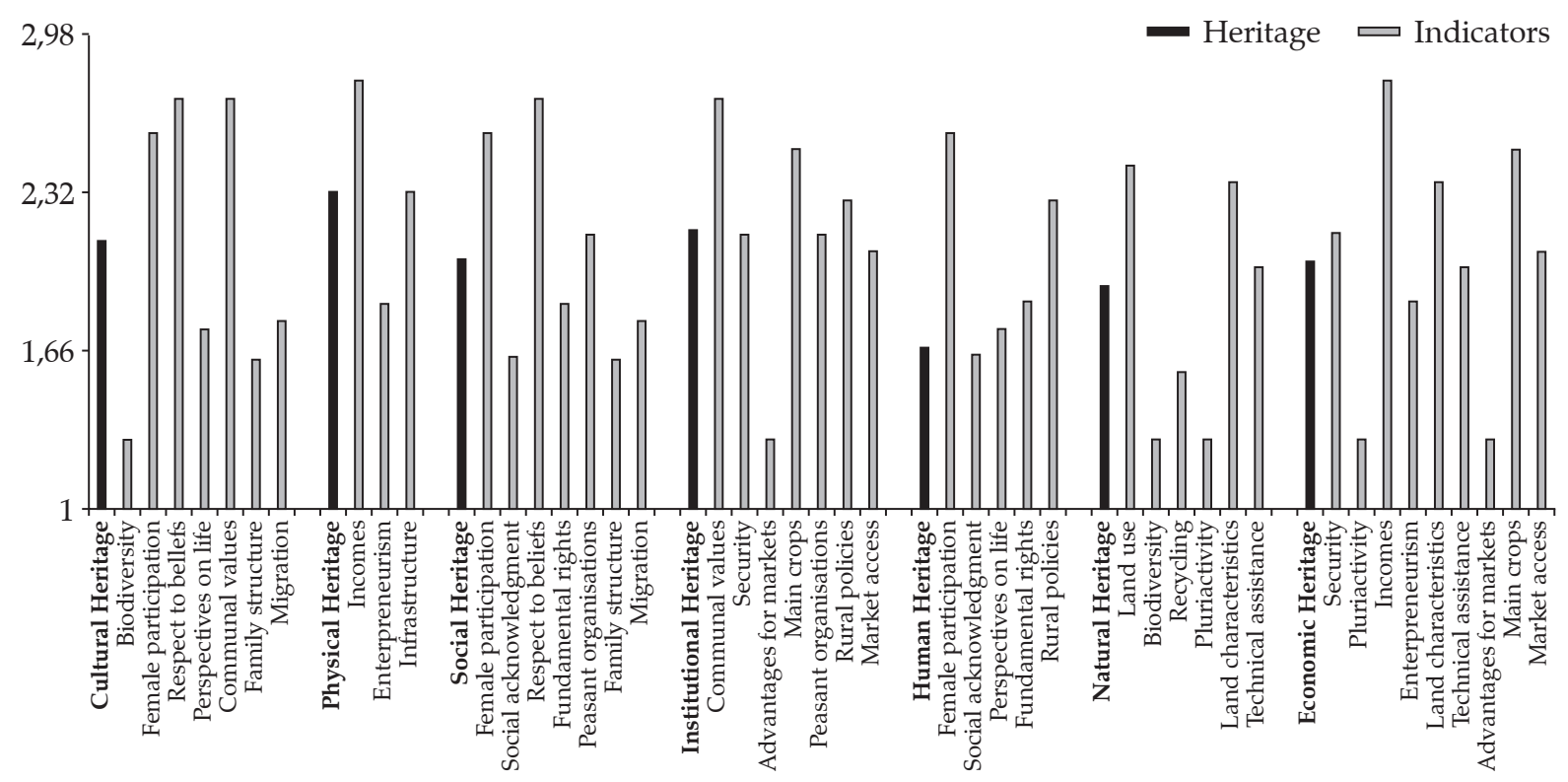

Source: Own elaboration. 
related to medical attention during the antenatal period and after childbirth. A family interviewed had 21 pregnancies, but unfortunately 8 of these babies died before the first year of life, which means an infant mortality rate of $38 \%$ in this family. According to Barham (2011), after the implementation of a Programme called Progresa that transfers money to the beneficiaries under the condition of attending the antenatal controls, the average infant mortality rate in the entire Mexican rural areas was 17,5 deaths per 1000 live births, which represents a $17 \%$ decline in this rate. Regarding the same indicator, coincidentally another family of a young couple with three children pointed out that at the moment of the second childbirth, the mother asked for a surgery to avoid getting pregnant again. However, the Catholic priest of the neighbourhood warned her that if she had such contraceptive surgery, she would suffer cancer seven years after. Another family with several children described the same story. That explains the strong influence that religion holds nowadays in rural areas, but at the same time, the lack of an adequate education programme in reproductive health with an emphasis in rural zones. There is little academic literature regarding this specific topic. However, it is important to highlight the role of the Catholic Church in the development of rural areas in Latin America. Balduíno (2001) describes the postulates of a part of this Institution to rural problems summarising that the Church will promote the participation of peasants in farmers organisations to claim for land, a real agrarian reform, and adequate public policies to improve the quality of life for all the countryside. Nevertheless, the most conservative branch of the Catholic Church has a strong influence as well on the reproductive behaviour of its practitioners. Sorhaindo, Karver, Karver and Garcia (2016) analyse the influence of religion on the behaviour of women regarding reproductive practices focusing on abortion in Mexico. The conclusion of the research is that older, poor and illiterate women are most influenced by the stigma of the religion at the moment of making decisions about sexual behaviour. It explains the findings in this region, but remarks that the strategy of generating fear to influence the reproductive behaviour of women could be extended to other regions of the country.

\subsection{Temascaltepec}

Temascaltepec is located at the South of the state of Mexico. Nevado de Toluca influences the entire region that is characterised by a solid agricultural production, but by a high rate of migration to the United States as well.

Figure 9 shows the level reached by the indicators and the Heritages of the Peasantry in Temascaltepec. Biodiversity, Recycling, Pluriactivity, Technical Assistance and Migration reached a low level. The reasons to get that level are similar to the ones in the other regions. However, special emphasis on Migration is important; for that reason, it will be described deeply later on. 
Figure 9. Results of Temascaltepec

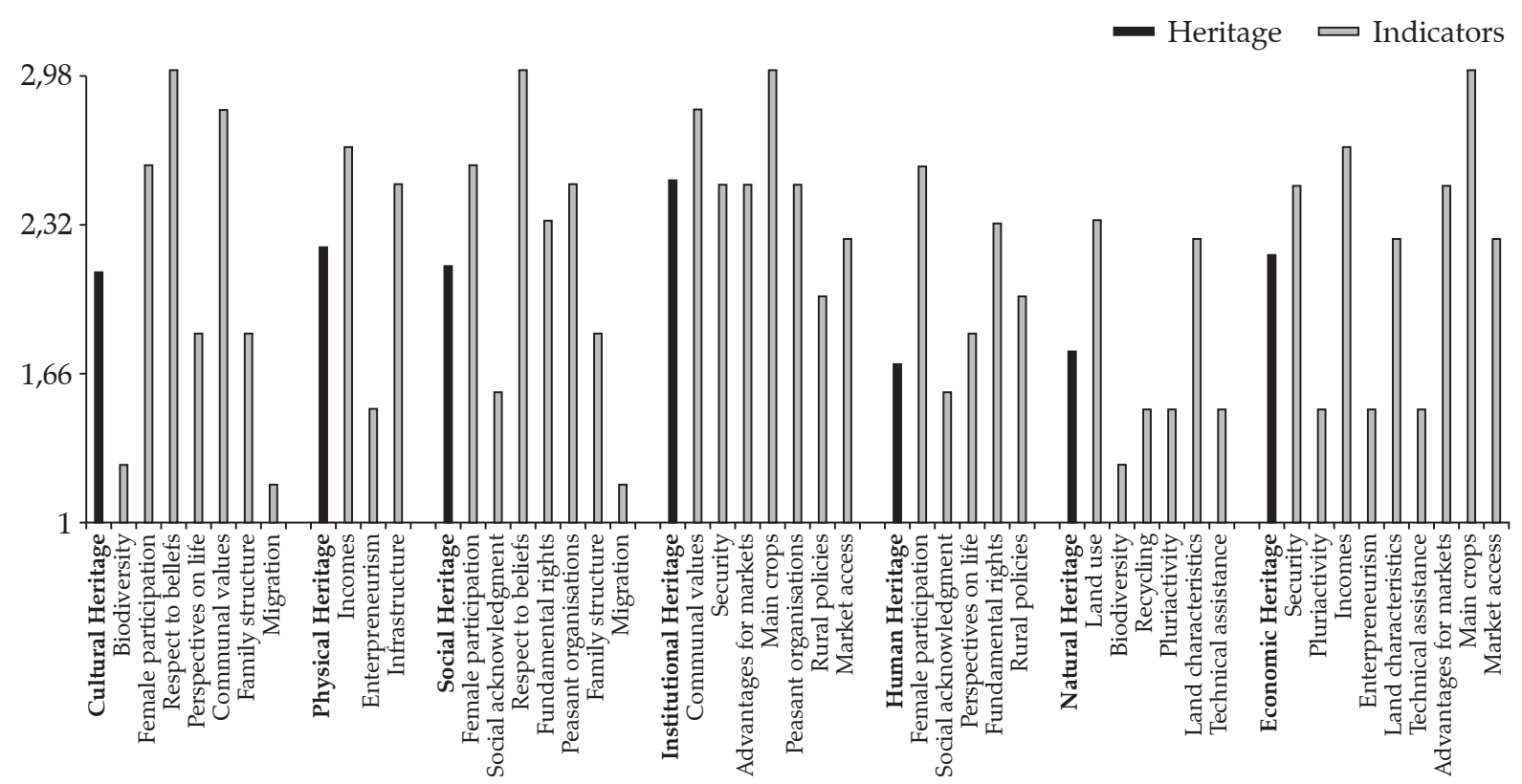

Source: Own elaboration.

In general terms, the entire Heritages show the same tendency as in the other regions. None of them are at low level, and the Institutional Heritage got the highest. The Natural Heritage got a low level because of the interactions of the indicators Biodiversity, Recycling and Technical Assistance. Taking into consideration the indicator Technical Assistance, the perception of the interviewed calls the attention because in the city, a university offers training in agricultural aspects. Besides, in Toluca, the capital city of the state, there is specialised training in agronomy and rural development.

Even though the indicator Migration got a low level, the Cultural and Social Heritages reached a medium level. However, Migration got the lowest level from all the regions in Temascaltepec. Mexican migration to the United States has been deeply described in economic and social aspects by (ARSLAN \& TAYLOR, 2012; TAYLOR \& LÓPEZ-FELDMAN, 2010), among many other authors. Apropos, it is significant to remark the thoughts of an interviewed, Fernando, concerning his experience about migration. Fernando was six years old when his father migrated to the United States and stayed there for 14 years. At the beginning his father sent remittances, and it was good because they were able to improve their house. Despite that, Fernando was always interested in agricultural production. That is why he continued planting the Milpa along with his mother and finally he studied agronomy at the University. When Fernando was 13 years old, his father did not send any more remittances because he had some problems with alcohol consumption and was in jail; for that reason, Fernando was responsible for the household incomes because his mother became ill and the saved money was spent on medical treatments.

Lara (2015) analyses the consequences of stories like Fernando's in a society, emphasising deeply on the costs, in social terms, of the loss of the parental guidance. In many cases educated people migrate looking for job opportunities because it is tough to get a good job in their own country. Fernando stated an explicit example of the costs for the society when he declares 
that regarding money and material assets, migration is good for the people who remain at home. However, the family ties are broken, and the children grow up without a complete parental guidance. He said, "It is like a society in war, without men". In many cases, but not in his, the migrants settle new families in the United States and they never come back home again. After his father returned, the relationship inside the family was difficult. "My papa is not my papa anymore, no one at home respects him", he said. "Nowadays, my father does not like the agricultural production. He wants to work on other things, but not in the countryside; he lost his identity, his culture, he is a different person".

\subsection{Breaking and Convergence Points}

Analysing the results of all the regions interviewed, the findings organise the discussion in themes especially linked to social concerns instead of productive matters, and four breaking points mediated by a parallelism or convergence could be described. The first breaking point is the importance of the self-recognition of the meaning of being peasants, which is related to the second aspect, the challenge of survival and the preservation of the peasantry as a culture. The third one is the concern about the proper arrangement of consumer packaging, narrowly related to environmental problems. Finally, the fourth breaking point is the acknowledgement of the loss of the diversities in the countryside. All these breaking points share a convergence point, which is that public policies are strongly related to agricultural production and leave people aside (RIVAS, BERNAL \& RODRÍGUEZ, 2016; LUJÁN, 2008).

Since the application of the North America Free Trade Agreement (NAFTA), the public policies of all the Mexican government have aimed to increase the agricultural production to be more comfortable in the new market created (HERRERA, 2009; HERRERA, LUTZ\&VIZCARRA, 2009). Clearly, the focus of the policies has been to create an atmosphere where the Mexican countryside should be able to take advantage of its conditions and reach these new consumers. In other words, the Mexican government creates a set of programmes to support farmers through subsidies, technical assistance, training, and the like, in order to promote competitiveness. Nevertheless, all these programmes leave the people living in the countryside in the oblivion, privileging their economic activities (RIVAS et al., 2016). This is the common denominator shared by all the breaking points analysed below and these policies are certainly the most responsible for the consequences of the current situation in the Mexican countryside.

Regarding the topic of the self-recognition of the meaning of being peasants, one of the aspects inquired was about the rural youth and their relationship with the pride of feeling a peasant. Most of the interviewed answered that young people are increasingly far from their peasant roots, and migrating to seek "better life opportunities in Mexican cities or another country" is a generalised desire Yaschine (2015) describes the ways the public policies in general have improved the indicators in items such as education, nutritional condition and health status. Nevertheless, these policies require adjustments for the purpose of increasing the level of education of the rural youth and then having the likelihood of doing rural activities better, or getting better rural jobs. Furthermore, the same author points out that the young migrants got lightly better jobs than those who remain in the countryside. This highlights at least two relevant facts: On the one hand, the kind of education for rural areas should offer in its curricula topics to encourage the pride of being peasants. However, on the other hand, the public policy should break the rigidity of the economic model applied in Latin America that avoids social mobility, especially for rural inhabitants and poor people. Instead, integral public policies should seek to reduce the inequalities, offering the possibility to get adequate salaries in rural areas, and hence well-being for rural people.

Along with the previous discussion, the second breaking point, the challenge of survival 
and the preservation of the peasantry as a culture could be analysed taking into consideration the migration from rural areas, which is a relevant concern because migration is generating an ageing process of the countryside. It is important to remark that migration is significant because it is breaking one of the main features of the peasantry, which is the importance of the family ties in the rural households. In this regard, Wanderley (2013) points out that being a peasant is a lifestyle based on the family bonds and its economic activity, agricultural production, is built on the effort of the family members working on it. Peasant economy is distinguished from other economic activities by the social practices of association, confidence and reciprocity, which belong to its behaviour, culture and traditions.

The end of the peasantry has been announced for extended time, nevertheless, the resilience and adaptability of the peasantry to new economic and productive scenarios have determined its survival (BERNSTEIN, 2010). The current reality of the countryside shows that, besides economic and productive concerns, the peasantry is being threatened by the ageing of its population, while the migration of young members is increasing. However, at the same time some people of the urban educated middle class, featured by a certain level of incomes level, are changing their minds about the meaning of the countryside and rural inhabitants, and are trying to recover some of their traditions and ways of production as an alternative to mitigate the problems resulting from the climatic change. Such change goes beyond the acknowledgement about the importance of the peasantry, it includes new consumer behaviour, and in some cases, settlement in the countryside, as it was described in the region of Etucuaro.

Despite the potential importance that migration and ageing hold for the peasantry, the interviewed described migration as a small problem in almost all the regions. Regarding this discussion, Echeverría and Fischer (2016) explain the "culture of migration" in Mexico as a social accepted and even encouraged behaviour in both urban and rural Mexico, which belongs to the standard life cycle for the youth, who have seen that many members of their families have explored alternatives off the countryside (SALAS \& DE OLIVEIRA, 2014). Nevertheless, the interviewed identified the scarcity of hand labour in the countryside, and the price that they must pay for it as a huge problem, maybe ignoring that it is a consequence of migration. That is why the indicator pluriactivity got a low level in all regions.

The third breaking point is a lightly analysed topic in the countryside: the proper arrangement of consumer packaging. This theme is becoming relevant because the consumer behaviour in rural areas is similar to the one in urban areas, which means that the amount of consumer packaging is increasing more and more, while the tradition of recycling or disposing these materials adequately is growing slowly. It is evident that in Latin America the culture of recycling is starting in the urban areas, while the process of appropriate management of organic and inorganic wastes is incipient in the countryside. Academic literature on the experiences of the recycling process in Latin American rural areas is scarce and just some systematised examples are remarkable (KREIGER, ANZALONE, MULDER, GLOVER \& PEARCE, 2013). Regarding this problem in Mexico, it is important to note that there is a public policy, which aims to gather a significant amount of plastic containers of agrochemicals. The initiative called the National Program of Gathering Empty Containers of Agrochemicals, and the like (PNREVAA- for its acronym in Spanish) started in 2013 (SAGARPA, 2013), However, an assessment of the impact of such program was unavailable. According to the answers of the interviewed, they usually burn or bury plastic bags and packaging, because they have no idea how to carry out an adequate disposal process. Certainly, it is an enormous problem that is currently growing up in the countryside, and hence it should be analysed to find alternatives to solve it, focusing on the rural youth who are probably more willing to tackle with it. 
The final breaking point is the acknowledgement of the loss of the diversities in the countryside. The term 'diversities' is used because beyond biodiversity, which was remarked as a low-level indicator in all the regions, there is a loss of cultural diversity, represented in the rural traditions. The questions asked to assess biodiversity concerns were related to two facts: the progressive loss of traditional seeds and the element of not seeing animals that were traditionally seen in the countryside some years ago. Martínez, Sosa and Álvarez (2014) deeply describe how Mexico is an important reserve for the biodiversity worldwide. However, according to that research, nowadays the total number of animal and plant species present in the country is unknown, which means that the rate of loss is uncertain due to the fact that an actual inventory is unavailable. Nevertheless, it is relevant to remark that it is a difficulty shared by almost all the countries that still have biodiversity richness, emphasising those from Africa and Latin America.

In order to clarify this issue, it is relevant to highlight that there is ample literature specifically about the process of loss of seeds, especially in corn. But some of them call the attention because they establish a relationship between the policies and the loss of traditional seeds. There is a coincidence between the applications of the particular reforms as a result of the NAFTA and the decrease of the total area cultivated with non-commercial varieties of corn for internal consumption such as 'Blue Corn' (Zea mays L.), base of the Mexican people's food (FOX \& HAIGHT, 2010; LUJÁN, 2008).

Along with this discussion, Bartra (2009) explains clearly that beyond the importance of corn for all the Mesoamerican inhabitants, they are "Milpa people". As it was discussed previously, Milpa is an old tradition of growing combined crops especially corn, beans, and pumpkins, but the mixture could contain other crops as well such as chillies or tomatoes. Bartra undoubtedly argues that in Mesoamerica the peasants do not grow corn; they cultivate Milpa, which is different. Milpa is in essence, the representation of biodiversity. Even though the area cultivated with corn is growing up in Mexico, such crop is a commercial production, with irrigation and intensive use of technology. On the other hand, the area cultivated with Milpa is decreasing, and is located in regions where water is scarce and depends just on the rain. Indeed, Mexico has passed from being sovereign in corn production, to be an importer of its most outstanding food (RUBIO, 2014).

In this scenario, the real threat for the Mexican peasantry, beyond the public policies, the climatic change, or the subsidies schemes in developed countries, is the loss of its culture. This started when the traditional way to produce was replaced by technologies that deplete soil fertility, avoid crops combination, contaminate water and increase the price of food. In other words, the current way to produce and the consumption behaviour of Mexican people is making them lose their diversity, from their own origin, from their own cultural plurality and the best way to understand such process is through the loss of the Milpa tradition.

\section{Conclusions}

This paper was seeking to examine the indicators of rural development based on the analytical framework Heritages and Patrimonies of the Peasantry, looking to establish the possible relationships among these indicators in six different regions in Mexico.

From the point of view of the level reached by the indicators and their interactions in the Patrimonies of the Peasantry, the main conclusion is that the Mexican society needs to recognise the importance of its countryside and the meaning of its peasantry. Nevertheless, the rural society needs to recognise that the culture of the country is the peasants and the rural inhabitants as well. Such recognition should take shape in public policies that cover the economic activities of the countryside, but also give importance to the conservation of the cultural traditions of 
the peasantry. In other words, policies should overcome a technocratic approach to rural development and privilege a political approach that respects the rights of all rural inhabitants.

From the point of view of the methodology, the main conclusion is that the indicators and the analytical framework are able to gather the perception of the peasants to show a picture of the countryside that remarks topics that usually people overlook. Essentially, the method shows topics different to those related to the economic activities of the rural areas, highlighting aspects such as the adequate disposition of waste or reproductive behaviour, among others. However, doing a better analysis of the countryside requires a complete series of data to verify changes in time. It is also important to consider the development of a methodology to identify the possible impact that public policies have on these indicators and the patrimonies, in order to make the best decision to benefit all rural inhabitants.

\section{References}

Aguirre, L. (2015). Technological resources design for ethical \& civic education: the Telesecondary experience in Mexico. Teoría de La Educación; Revista Interuniversitaria, 27 (1), 137.

Aranda, S. (2013). Stories of drug trafficking in rural Mexico: territories, drugs and cartels in Michoacán. European Review of Latin American and Caribbean Studies/ Revista Europea de Estudios Latinoamericanos Y Del Caribe, 43-66.

Arslan, A. \& Taylor, J. (2012). Transforming rural economies: migration, income generation and inequality in rural Mexico. Journal of Development Studies, 48 (8), 1156-1176. https://doi.org/10.1080/00220 388.2012.682985

Balduíno T. (2001). A ação da Igreja Católica e o desenvolvimento rural. Estudos Avançados, 15, 9-22.

Barham, T.(2011). A healthierstart:The effect of conditional cash transfers on neonatal and infant mortality in rural Mexico. Journal of Development Economics, 94 (1), 74-85. https://doi.org/10.1016/j.jdeveco.2010.01.003

Bartra, A. (2009). Hacer milpa. Ciencias, 92 (092).

Bernstein, H. (2010). Class dynamics of agrarian change (Vol. 1). Winnipeg: Kumarian Press.
Boisier, S. (2003). ¿ Y si el desarrollo fuese una emergencia sistémica. Revista Del CLAD Reforma $Y$ Democracia, 27, 11-29.

Castro, G. (2014). Nuestra Guerra Ajena (I). Bogotá: Editorial Planeta Colombiana.

Chambers, R. (1983). Rural development: Putting the last first. Routledge.

Desmarais, A. (2008). The power of peasants: Reflections on the meanings of La Vía Campesina. Social Movements and Rural Politics, 24 (2), 138-149. https://doi.org/10.1016/j.jrurstud.2007.12.002

de Sousa Santos, B. \& Meneses, M. (2010). Epistemologias do Sul. Cortez Editora.

Díaz, A. \& Pérez, G. (2015). Violencia y autodefensas comunitarias en Michoacán, México. Íconos-Revista de Ciencias Sociales, 19 (53), 171-186.

Echeverría, M. \& Fischer, P. (2016). Jóvenes con intención de salir. Cultura de la migración en estudiantes de Yucatán. Península, 11 (2), 9-33. https://doi.org/10.1016/j. pnsla.2016.08.001

Ely, P. (2013). Selling Mexico: Marketing and tourism values. Tourism Management Perspectives, 8, 80-89. https://doi.org/10.1016/j.tmp.2013.07.003

Escobar, A. (1998). La invención del Tercer Mundo: Construcción y deconstrucción del desarrollo. Editorial Norma.

Fox, J. \& Haight, L. (2010). Subsidios para la desigualdad. Las políticas públicas del maíz en México a partir del libre comercio. Woodrow Wilson International Center for Scholars, Centro de Investigación y Docencia Económicas, University of California, Santa Cruz.

Fulbright, T. E. \& Ortega, J. (2007). Ecología y manejo de venado cola blanca. Texas A\&M University Press.

Herrera, F. (2009). Apuntes sobre las instituciones y los programas de desarrollo rural en México: Del Estado benefactor al Estado neoliberal. Estudios Sociales (Hermosillo, Son.), 17, 7-39.

Herrera, F., Lutz, B. \& Vizcarra, I. (2009). La política de desarrollo rural en México y el cambio institucional 2000-2006. Economía, Sociedad Y Territorio, 9, 89-117.

Huacuja, F. (2008). Abriendo fronteras: El auge exportador del aguacate mexicano a Estados Unidos1/Opening markets: the mexican avocado export boom to USA (Vol. 28, pp. 9-28). Presented at the Anales de Geografía de la Universidad Complutense, Universidad Complutense de Madrid.

Jaen, C., Aragón, S., Amorin, E. \& Rivera, L. (2015). Violencia de Pareja en Mujeres: Prevalencia y Factores Asociados. Acta de Investigación Psicológica, 5 (3), 22242239. https://doi.org/10.1016/S2007-4719(16)30012-6 
Kay, C. (2005). Enfoques sobre el Desarrollo Rural en América Latina y Europa desde Mediados del Siglo Veinte [Versión electrónica]. Institute of Social Studies de La Haya. Consultado El, 31.

Kreiger, M., Anzalone, G., Mulder, M., Glover, A. \& Pearce, J. (2013). Distributed Recycling of PostConsumer Plastic Waste in Rural Areas. MRS Online Proceedings Library Archive, 1492, 91-96. https://doi. org/10.1557/opl.2013.258

Lara, J. (2015). International migration and human capital in Mexico: Networks or parental absence? International Journal of Educational Development, 41, 131142. https://doi.org/10.1016/j.ijedudev.2015.02.006

Luján, J. (2008). Desde los colores del maíz: Una agenda para el campo mexicano (Vol. 2). El Colegio de Michoacán.

Martínez, J., Bonales, J., Zamudio, A. \& Gaytan, J. (2011). Competitiveness's Determinants in the Avocado Export Sector's Value Chain. Journal of Stored Products and Posthervest Research, 2 (4), 59-63.

Martínez E., Sosa, J. \& Álvarez, F. (2014). El estudio de la biodiversidad en México: ¿una ruta con dirección? Revista Mexicana de Biodiversidad, 85 (Supplement 1), 1-9. https://doi.org/10.7550/rmb.43248

Montes, M. (2014). 'Clean Pulque' / 'Dirty Pulque': Disputes about legitimacy and the social production of value. Revista Colombiana de Antropología, 50 (2), 41-63.

Pachón, F., Bokelmann, W. \& Ramirez, C. (2015). Rural Development Indicators Based on Food Sovereignty Principales: A methodology for its Selection. Presented at the 78th Annual Meeting of Rural Sociological Society. Knowing Rural: Situating the Lived Experience of Rurality in Definitions of Rural., Madison, Wisconsin. USA.

Pachón, F., Bokelmann, W. \& Ramirez, C. (2016a). Rural development thinking, moving from the green revolution to food sovereignty. Agronomía Colombiana, 34 (2), 267-276. https://doi.org/Doi:10.15446/agron. colomb.v34n2.56639

Pachón, F., Bokelmann, W. \& Ramirez, C. (2016b). Heritages of the peasantry: An analytical framework to address rural development. Presented at the 4th Biannual Conference on Nordic Rural Research, Akureyri.

Pachón, F., Bokelmann, W. \& Ramirez, C. (2017). Heritage and Patrimony of the Peasantry Framework to Address Rural Development and Application in Colombia. Acta Agronómica, 66 (3), 347-359. https://doi. org/10.15446/acag.v66n3.60949.

Reyes, A. (2014). Adolescencias rurales, telesecundarias y experiencias estudiantiles. Argumentos (México, DF), 27 (74), 75-93.

Rivas, Bernal, L. \& Rodríguez, A. V. (2016). La política rural en México en la etapa del tlcan y su efecto en la productividad agrícola de la región centro-norte del país (Vol. 9, pp. 1001-1018). Presented at the Memorias del Congreso de la Red Internacional de Investigadores en Competitividad.

Rubio, B. (2014). El dominio del hambre: Crisis de hegemonía y alimentos. Universidad Autónoma Chapingo. Colegio de Postgraduados. Universidad Autónoma de Zacatecas. Juan Pablos Editor.

Sagarpa (2013). Sin envases vacíos, seguro hay icampo limpio! Retrieved from https://www.gob.mx/sagarpa/ articulos/sin-envases-vacios-seguro-hay-campolimpio?idiom $=\mathrm{es}$

Salas, M. \& de Oliveira, O. (2014). Los caminos de la vida: acumulación, reproducción o superación de las desventajas sociales en México. Revista Mexicana de Ciencias Políticas Y Sociales, 59 (220), 81-115. https://doi. org/10.1016/S0185-1918(14)70802-5

Secretaría de Infraestructura de Mexico (2016, December 17). Infraestructura: Datos Abiertos para el desarrollo de la infraestructura como pieza clave para incrementar la competitividad. Retrieved from http:// datos.gob.mx/categoria/infraestructura

Silva, V. \& García, Y. C. (2015). Michoacan Mezcal: Origen and comercialization (Vol. 10, p. 1364). Presented at the Global Conference on Business \& Finance Proceedings, Institute for Business \& Finance Research.

Sorhaindo, A., Karver, T., Karver, J. \& Garcia, S. (2016). Constructing a validated scale to measure communitylevel abortion stigmain Mexico. Contraception, 93 (5), 421431. https://doi.org/10.1016/j.contraception.2016.01.013

Taylor, J. \& López, A. (2010). Does migration make rural households more productive? Evidence from Mexico. The Journal of Development Studies, 46 (1), 68-90. https:// doi.org/10.1080/00220380903198463

Villaseñor, G. (Ed.). (2005). La biodiversidad en Michoacán: Estudio de caso. Mexico: Comisión Nacional para el Conocimiento y Uso de la Biodiversidad, Secretaría de Urbanismo y Medio Ambiente, Universidad Michoacana de San Nicolás de Hidalgo.

Wanderley, M. (2013). Agricultura familiar e campesinato: rupturas e continuidade. Estudos Sociedade E Agricultura, 1.

World Bank (2016, December 17). The World Bank Data by Country. Retrieved from http://data.worldbank.org/ country $/$ mexico?view $=$ chart

Yaschine, I. (2015). ¿Alcanza la educación para salir de la pobreza? Análisis del proceso de estratificación ocupacional de jóvenes rurales en México1. Revista Mexicana de Ciencias Políticas Y Sociales, 60 (223), 377405. https://doi.org/10.1016/S0185-1918(15)72142-2 


\section{Annex 1}

\begin{tabular}{|c|c|c|c|}
\hline Heritages & Indicator & Questions/criteria & Levels \\
\hline \multirow{30}{*}{$\begin{array}{l}\text { Cultural } \\
\text { Heritage }\end{array}$} & \multirow[t]{6}{*}{ Biodiversity } & \multirow{3}{*}{$\begin{array}{l}\text { Have peasants here stopped } \\
\text { planting some seeds that } \\
\text { were used } 30 \text { years ago? }\end{array}$} & 1. Yes (Examples) \\
\hline & & & 2.We stopped using, but nowadays we are planting again \\
\hline & & & 3. No (Examples) \\
\hline & & \multirow{3}{*}{$\begin{array}{l}\text { Have peasants here stopped } \\
\text { watching some (wild) } \\
\text { animals that were watched } \\
30 \text { years ago? }\end{array}$} & 1. Yes (Examples) \\
\hline & & & 2.We stopped watching, but nowadays we are watching again \\
\hline & & & 3. No (Examples) \\
\hline & \multirow{6}{*}{$\begin{array}{l}\text { Female } \\
\text { Participation }\end{array}$} & \multirow{3}{*}{$\begin{array}{l}\text { Who makes decisions at } \\
\text { home? }\end{array}$} & 1. Men \\
\hline & & & 2. Women \\
\hline & & & 3. Shared with all the family \\
\hline & & \multirow{3}{*}{$\begin{array}{l}\text { Does domestic violence exist } \\
\text { in your neighbourhood? }\end{array}$} & 1. Yes \\
\hline & & & 2. Sometimes \\
\hline & & & 3. No \\
\hline & \multirow[t]{3}{*}{ Respect to Beliefs } & \multirow{3}{*}{$\begin{array}{l}\text { Do people respect the beliefs } \\
\text { of other people at home and } \\
\text { in your neighbourhood? }\end{array}$} & 1. No \\
\hline & & & 2. Sometimes \\
\hline & & & 3. Yes \\
\hline & \multirow{3}{*}{$\begin{array}{l}\text { Communal } \\
\text { Values }\end{array}$} & \multirow{3}{*}{$\begin{array}{l}\text { Is solidarity a characteristic } \\
\text { of the neighbours when a } \\
\text { difficult situation happens? }\end{array}$} & 1. No \\
\hline & & & 2. Sometimes \\
\hline & & & 3. Yes \\
\hline & \multirow[t]{6}{*}{ Migration } & \multirow{3}{*}{$\begin{array}{l}\text { Has a member of your family } \\
\text { migrated in the last five } \\
\text { years? }\end{array}$} & 1. Yes \\
\hline & & & 2. No \\
\hline & & & 3. Someone migrated to study, but returned \\
\hline & & \multirow{3}{*}{$\begin{array}{l}\text { The availability of hand } \\
\text { labour is... }\end{array}$} & 1. Not available \\
\hline & & & 2. Scarce \\
\hline & & & 3. Abundant \\
\hline & \multirow[t]{6}{*}{ Family Structure } & \multirow[t]{3}{*}{ Education level } & 1. At least one family member does not know how to write and read \\
\hline & & & 2. At least one family member that is at school age is not studying \\
\hline & & & 3. All family members have finished at least secondary school \\
\hline & & \multirow[t]{3}{*}{ Occupation } & 1. At least one family member does not work \\
\hline & & & 2. All family members are working outside the farm \\
\hline & & & 3. At least one family member is working off the farm \\
\hline \multirow{15}{*}{$\begin{array}{l}\text { Physical } \\
\text { Heritage }\end{array}$} & \multirow[t]{12}{*}{ Incomes } & \multirow{3}{*}{$\begin{array}{l}\text { Do you currently have a } \\
\text { loan? }\end{array}$} & 1. Yes, with non traditional institutions \\
\hline & & & 2. Yes, with traditional institutions \\
\hline & & & 3. No, I do not have any \\
\hline & & \multirow{3}{*}{$\begin{array}{l}\text { Have you received any } \\
\text { subsidies from the government } \\
\text { over the past five years? }\end{array}$} & 1. No, I have never received \\
\hline & & & 2. I have received, but currently I don't have any \\
\hline & & & 3. Yes, currently I have \\
\hline & & \multirow[t]{3}{*}{ You use your incomes to... } & 1. Pay loans \\
\hline & & & 2. Buy inputs (seeds, fertilisers, and so on \\
\hline & & & 3. Ensure family welfare \\
\hline & & \multirow{3}{*}{$\begin{array}{l}\text { Who makes the decisions } \\
\text { about how to spend the } \\
\text { family incomes? }\end{array}$} & 1. Men \\
\hline & & & 2. Women \\
\hline & & & 3. Shared with all the family \\
\hline & \multirow[t]{3}{*}{ Entrepreneurism } & & 1. No \\
\hline & & belong to a new enterprise to & 2. Currently we do not belong \\
\hline & & & 3. Yes \\
\hline
\end{tabular}




\begin{tabular}{|c|c|c|c|}
\hline \multirow{27}{*}{$\begin{array}{l}\text { Physical } \\
\text { Heritage }\end{array}$} & \multirow[t]{27}{*}{ Infrastructure } & \multirow{3}{*}{$\begin{array}{l}\text { Access to roads in your } \\
\text { neighbourhood is }\end{array}$} & 1. Bad \\
\hline & & & 2. Regular \\
\hline & & & 3. Good \\
\hline & & \multirow{3}{*}{$\begin{array}{l}\text { Access to schools in your } \\
\text { neighbourhood is }\end{array}$} & 1. Bad \\
\hline & & & 2. Regular \\
\hline & & & 3. Good \\
\hline & & \multirow{3}{*}{$\begin{array}{l}\text { Access to electricity in your } \\
\text { neighbourhood is }\end{array}$} & 1. Bad \\
\hline & & & 2. Regular \\
\hline & & & 3. Good \\
\hline & & \multirow{3}{*}{$\begin{array}{l}\text { Access to communication } \\
\text { services in your } \\
\text { neighbourhood is }\end{array}$} & 1. Bad \\
\hline & & & 2. Regular \\
\hline & & & 3. Good \\
\hline & & \multirow{3}{*}{$\begin{array}{l}\text { Access to transport network } \\
\text { in your neighbourhood is }\end{array}$} & 1. Bad \\
\hline & & & 2. Regular \\
\hline & & & 3. Good \\
\hline & & \multirow{3}{*}{$\begin{array}{l}\text { Access to health centres in } \\
\text { your neighbourhood is }\end{array}$} & 1. Bad \\
\hline & & & 2. Regular \\
\hline & & & 3. Good \\
\hline & & \multirow{3}{*}{$\begin{array}{l}\text { Access to irrigation in your } \\
\text { neighbourhood is }\end{array}$} & 1. Bad \\
\hline & & & 2. Regular \\
\hline & & & 3. Good \\
\hline & & \multirow{3}{*}{$\begin{array}{l}\text { Access to restroom s in the } \\
\text { house is }\end{array}$} & 1. Bad \\
\hline & & & 2. Regular \\
\hline & & & 3. Good \\
\hline & & \multirow{3}{*}{$\begin{array}{l}\text { Access to clean water in your } \\
\text { home is }\end{array}$} & 1. Bad \\
\hline & & & 2. Regular \\
\hline & & & 3. Good \\
\hline \multirow{33}{*}{$\begin{array}{l}\text { Social } \\
\text { Heritage }\end{array}$} & \multirow{6}{*}{$\begin{array}{l}\text { Female } \\
\text { Participation }\end{array}$} & \multirow{3}{*}{$\begin{array}{l}\text { At home, who makes the } \\
\text { decisions? }\end{array}$} & 1. Men \\
\hline & & & 2. Women \\
\hline & & & 3. Shared with all the family \\
\hline & & \multirow{3}{*}{$\begin{array}{l}\text { Does domestic violence exist } \\
\text { in your neighbourhood? }\end{array}$} & 1. Yes \\
\hline & & & 2. Sometimes \\
\hline & & & 3. No \\
\hline & \multirow{6}{*}{$\begin{array}{l}\text { Social } \\
\text { Acknowledgment }\end{array}$} & \multirow{3}{*}{$\begin{array}{l}\text { Do you think current rural } \\
\text { life is better than } 10 \text { years } \\
\text { ago? }\end{array}$} & 1. It is less equitable \\
\hline & & & 2. It is equal \\
\hline & & & 3. It is more equitable \\
\hline & & & 1. No \\
\hline & & to be peasants in your & 2. Some times \\
\hline & & & 3. Yes \\
\hline & Respect to Beliefs & Do people respect the beliefs & 1. No \\
\hline & & of other people at home and & 2. Sometimes \\
\hline & & in your neighbourhood? & \begin{tabular}{|l|} 
3. Yes \\
\end{tabular} \\
\hline & Fundamental & Access to education in your & 1. Bad \\
\hline & Rights & family is & 2. Regular \\
\hline & & & 3. Good \\
\hline & & Access to information (TV, & 1. Bad \\
\hline & & radio, newspaper,) in your & 2. Regular \\
\hline & & family is & 3. Good \\
\hline & & Access to education in your & 1. Bad \\
\hline & & family is & 2. Regular \\
\hline & & & 3. Good \\
\hline & & Access to culture in your & 1. Bad \\
\hline & & neighbourhood is & 2. Regular \\
\hline & & & 3. Good \\
\hline & & Access to health services in & 1. Bad \\
\hline & & your neighbourhood is & 2. Regular \\
\hline & & & 3. Good \\
\hline & & Access to old age pension in & 1. Bad \\
\hline & & your family is & 2. Regular \\
\hline & & & 3. Good \\
\hline
\end{tabular}


222 Heritage and Patrimony of the Peasantry Framework and Rural Development Indicators in Rural Communities in Mexico

\begin{tabular}{|c|c|c|c|}
\hline \multirow{15}{*}{$\begin{array}{l}\text { Social } \\
\text { Heritage }\end{array}$} & \multirow{3}{*}{$\begin{array}{l}\text { Peasant } \\
\text { Organisations }\end{array}$} & \multirow{3}{*}{$\begin{array}{l}\text { Do you think that belonging } \\
\text { to a peasant organisation has } \\
\text { advantages? }\end{array}$} & 1. No, never \\
\hline & & & 2. Sometimes \\
\hline & & & 3. Yes, always \\
\hline & \multirow[t]{6}{*}{ Family Structure } & \multirow[t]{3}{*}{ Education level } & 1. At least one family member does not know how to write and read \\
\hline & & & 2. At least one family member that is at school age is not studying \\
\hline & & & 3. All family members have finished at least secondary school \\
\hline & & \multirow[t]{3}{*}{ Occupation } & 1. At least one family member does not work \\
\hline & & & 2. All family members are working outside the farm \\
\hline & & & 3. At least one family member is working outside the farm \\
\hline & \multirow[t]{6}{*}{ Migration } & \multirow{3}{*}{$\begin{array}{l}\text { Has a member of your family } \\
\text { migrated in the last five } \\
\text { years? }\end{array}$} & 1. Yes \\
\hline & & & 2. No \\
\hline & & & 3. Someone migrated to study but returned \\
\hline & & \multirow{3}{*}{$\begin{array}{l}\text { The availability of hand } \\
\text { labour is... }\end{array}$} & 1. Non existent \\
\hline & & & 2. Scarce \\
\hline & & & 3. Abundant \\
\hline \multirow{39}{*}{\begin{tabular}{l|} 
Institutional \\
Heritage
\end{tabular}} & \multirow{3}{*}{$\begin{array}{l}\text { Communal } \\
\text { Values }\end{array}$} & \multirow{3}{*}{$\begin{array}{l}\text { Is solidarity a characteristic } \\
\text { behaviour of the relatives } \\
\text { and neighbours when a } \\
\text { difficult situation happens? }\end{array}$} & 1. No \\
\hline & & & 2. Sometimes \\
\hline & & & 3. Yes \\
\hline & \multirow[t]{3}{*}{ Security } & \multirow{3}{*}{$\begin{array}{l}\text { Do you think your } \\
\text { neighbourhood is safer than } \\
\text { others? }\end{array}$} & 1. No \\
\hline & & & 2. Sometimes \\
\hline & & & 3. Yes \\
\hline & \multirow{6}{*}{$\begin{array}{l}\text { Advantages for } \\
\text { Markets }\end{array}$} & \multirow{3}{*}{$\begin{array}{l}\text { Do you currently harvest any } \\
\text { special products? (Organic, } \\
\text { green label, etc?) }\end{array}$} & 1. No, currently I do not \\
\hline & & & 2. No, I did, but currently I do not \\
\hline & & & 3. Yes, I do \\
\hline & & \multirow{3}{*}{$\begin{array}{l}\text { Do you do any post harvest } \\
\text { management? }\end{array}$} & 1. No, currently I do not \\
\hline & & & 2. No, I did but currently I do not \\
\hline & & & 3. Yes, I do \\
\hline & \multirow[t]{9}{*}{ Main Crops } & \multirow{3}{*}{$\begin{array}{l}\text { The production in your first } \\
\text { most important/activity crop } \\
\text { is... }\end{array}$} & 1. Less than the average \\
\hline & & & 2. Equal than the average \\
\hline & & & 3. Superior to the average \\
\hline & & \multirow{3}{*}{$\begin{array}{l}\text { The production in your } \\
\text { second most important/ } \\
\text { activity crop is... }\end{array}$} & 1. Less than the average \\
\hline & & & 2. Equal than the average \\
\hline & & & 3. Superior to the average \\
\hline & & The production in your third & 1. Less than the average \\
\hline & & most important/activity crop & 2. Equal than the average \\
\hline & & & 3. Superior to the average \\
\hline & Rural Policies & Do you think national rural & 1. No \\
\hline & & policies are adequate? & 2. Sometimes \\
\hline & & & 3. Yes \\
\hline & & Can peasants in your & 1. No \\
\hline & & $\begin{array}{l}\text { neighbourhood participate } \\
\text { in the spaces where the }\end{array}$ & 2. Sometimes \\
\hline & & decisions are made? & 3. Yes \\
\hline & Access to & Where do you sell your & 1. To intermediaries \\
\hline & Markets & products? & 2. In a market close to the farm \\
\hline & & & 3. In the farm \\
\hline & & How do people pay for your & 1. Over 60 days \\
\hline & & products? & \begin{tabular}{|l|}
2.30 days maximum \\
\end{tabular} \\
\hline & & & 3. Immediately \\
\hline & & & 1. Yes \\
\hline & & $\begin{array}{l}\text { the harvest the same that } \\
\text { sell the fertilisers in your }\end{array}$ & 2. It happened, but nowadays it does not \\
\hline & & neighbourhood? Monopoly & 3. No \\
\hline & & Do you prefer selling the & 1. No \\
\hline & & harvest altogether with your & 2. Sometimes \\
\hline & & & 3. Yes \\
\hline
\end{tabular}




\begin{tabular}{|c|c|c|c|}
\hline \multirow{45}{*}{$\begin{array}{l}\text { Human } \\
\text { Heritage }\end{array}$} & \multirow{6}{*}{$\begin{array}{l}\text { Female } \\
\text { Participation }\end{array}$} & \multirow{3}{*}{$\begin{array}{l}\text { Who makes decisions at } \\
\text { home? }\end{array}$} & 1. Men \\
\hline & & & 2. Women \\
\hline & & & 3. Shared with all the family \\
\hline & & \multirow{3}{*}{$\begin{array}{l}\text { Does domestic violence exist } \\
\text { in your neighbourhood? }\end{array}$} & 1. Yes \\
\hline & & & 2. Sometimes \\
\hline & & & 3. No \\
\hline & \multirow{6}{*}{$\begin{array}{l}\text { Social } \\
\text { Acknowledgment }\end{array}$} & \multirow{3}{*}{$\begin{array}{l}\text { Do you think current rural } \\
\text { life is better than } 10 \text { years } \\
\text { ago? }\end{array}$} & 1. It is less equitable \\
\hline & & & 2. It is equal \\
\hline & & & 3. It is more equitable \\
\hline & & \multirow{3}{*}{$\begin{array}{l}\text { Are young people proud } \\
\text { to be peasants in your } \\
\text { neighbourhood? }\end{array}$} & 1. No \\
\hline & & & 2. Some times \\
\hline & & & 3. Yes \\
\hline & \multirow{12}{*}{$\begin{array}{l}\text { Perspectives on } \\
\text { Life }\end{array}$} & \multirow{3}{*}{$\begin{array}{l}\text { Do you usually rest on } \\
\text { Sundays or weekends? }\end{array}$} & $1 . \mathrm{No}$ \\
\hline & & & 2. Some times \\
\hline & & & 3. Yes \\
\hline & & \multirow{3}{*}{$\begin{array}{l}\text { Do you think the future of } \\
\text { rural areas will be better? }\end{array}$} & 1. No \\
\hline & & & 2. Probably \\
\hline & & & 3. Yes \\
\hline & & \multirow{3}{*}{$\begin{array}{l}\text { Is special attention paid to } \\
\text { women during the pregnancy } \\
\text { and after the childbirth in } \\
\text { your neighbourhood? }\end{array}$} & 1. No \\
\hline & & & 2. Some times \\
\hline & & & 3. Yes \\
\hline & & \multirow{3}{*}{$\begin{array}{l}\text { Are there any problems with } \\
\text { alcohol consumption in your } \\
\text { neighbourhood? }\end{array}$} & 1. No \\
\hline & & & 2. Some times \\
\hline & & & 3. Yes \\
\hline & \multirow{15}{*}{$\begin{array}{l}\text { Fundamental } \\
\text { Rights }\end{array}$} & \multirow{3}{*}{$\begin{array}{l}\text { Access to education in your } \\
\text { family is }\end{array}$} & 1. Bad \\
\hline & & & 2. Regular \\
\hline & & & 3. Good \\
\hline & & \multirow{3}{*}{$\begin{array}{l}\text { Access to information (TV, } \\
\text { radio, newspaper, ) in your } \\
\text { family is }\end{array}$} & 1. Bad \\
\hline & & & 2. Regular \\
\hline & & & 3. Good \\
\hline & & \multirow{3}{*}{$\begin{array}{l}\text { Access to culture in your } \\
\text { neighbourhood is }\end{array}$} & 1. Bad \\
\hline & & & 2. Regular \\
\hline & & & 3. Good \\
\hline & & \multirow{3}{*}{$\begin{array}{l}\text { Access to health services in } \\
\text { your neighbourhood is }\end{array}$} & 1. Bad \\
\hline & & & 2. Regular \\
\hline & & & 3. Good \\
\hline & & \multirow{3}{*}{$\begin{array}{l}\text { Access to old age pension in } \\
\text { your family is }\end{array}$} & 1. Bad \\
\hline & & & 2. Regular \\
\hline & & & 3. Good \\
\hline & \multirow[t]{6}{*}{ Rural Policies } & \multirow{3}{*}{$\begin{array}{l}\text { Do you think national rural } \\
\text { policies are adequate? }\end{array}$} & 1. No \\
\hline & & & 2. Sometimes \\
\hline & & & 3. Yes \\
\hline & & Can peasants in your & 1. No \\
\hline & & $\begin{array}{l}\text { neighbourhood participate } \\
\text { in the spaces where the }\end{array}$ & 2. Sometimes \\
\hline & & decisions are made? & 3. Yes \\
\hline Natural & Land Use & Do you use your farm for... & 1. Livestock \\
\hline Heritage & & & 2. Monoculture \\
\hline & & & 3. Polyculture \\
\hline & & Do you have a kind of soil & 1. No, never \\
\hline & & conservation practice? & 2. Sometimes \\
\hline & & & 3. Yes, always \\
\hline & & Are you the owner of the & 1. No \\
\hline & & farm? & 2. Leasing \\
\hline & & & 3. Yes \\
\hline
\end{tabular}


224 - Heritage and Patrimony of the Peasantry Framework and Rural Development Indicators in Rural Communities in Mexico

\begin{tabular}{|c|c|c|c|}
\hline \multirow{18}{*}{$\begin{array}{l}\text { Natural } \\
\text { Heritage }\end{array}$} & \multirow[t]{6}{*}{ Biodiversity } & \multirow{3}{*}{$\begin{array}{l}\text { Have peasants here stopped } \\
\text { planting some seeds that } \\
\text { were used } 30 \text { years ago? }\end{array}$} & 1. Yes (Examples) \\
\hline & & & 2.We stopped using, but nowadays we are planting again \\
\hline & & & 3. No (Examples) \\
\hline & & \multirow{3}{*}{$\begin{array}{l}\text { Have peasants here stopped } \\
\text { watching some (wild) } \\
\text { animals that were watched } \\
30 \text { years ago? }\end{array}$} & 1. Yes (Examples) \\
\hline & & & 2.We stopped watching, but nowadays we are watching again \\
\hline & & & 3. No (Examples) \\
\hline & \multirow[t]{3}{*}{ Recycling } & \multirow{3}{*}{$\begin{array}{l}\text { Do you have a practice to } \\
\text { recycle at home? }\end{array}$} & 1. No \\
\hline & & & 2. Long time ago, but nowadays no \\
\hline & & & 3. Yes \\
\hline & \multirow{3}{*}{$\begin{array}{l}\text { Technical } \\
\text { Assistance }\end{array}$} & \multirow{3}{*}{$\begin{array}{l}\text { The quality of the technical } \\
\text { assistance you receive is... }\end{array}$} & 1. Low \\
\hline & & & 2. Medium \\
\hline & & & 3. High \\
\hline & \multirow{6}{*}{$\begin{array}{l}\text { Land } \\
\text { Characteristics }\end{array}$} & \multirow{3}{*}{$\begin{array}{l}\text { The high share of your farm } \\
\text { is used ... }\end{array}$} & 1. Contrary to the soil type \\
\hline & & & 2. Partly according to the soil type \\
\hline & & & 3. According to the soil type \\
\hline & & \multirow{3}{*}{$\begin{array}{l}\text { Do you think the quality of } \\
\text { the soil in your farm is... }\end{array}$} & 1. Low \\
\hline & & & 2. Medium \\
\hline & & & 3. High \\
\hline \multirow{39}{*}{$\begin{array}{l}\text { Economic } \\
\text { Heritage }\end{array}$} & \multirow[t]{3}{*}{ Security } & \multirow{3}{*}{$\begin{array}{l}\text { Do you think your } \\
\text { neighbourhood is safer than } \\
\text { others? }\end{array}$} & 1. No \\
\hline & & & 2. Sometimes \\
\hline & & & 3. Yes \\
\hline & \multirow[t]{6}{*}{ Pluriactivity } & \multirow{3}{*}{$\begin{array}{l}\text { Are members of your family } \\
\text { working off the farm? }\end{array}$} & 1. Men and women \\
\hline & & & 2. Nobody \\
\hline & & & 3. Just men \\
\hline & & \multirow{3}{*}{$\begin{array}{l}\text { When they work off the } \\
\text { farm, they do it ... }\end{array}$} & 1. Full time \\
\hline & & & 2. Part time \\
\hline & & & 3. In a hand labour scheme (minga) \\
\hline & \multirow{12}{*}{ Incomes } & \multirow{3}{*}{$\begin{array}{l}\text { Do you currently have a } \\
\text { loan? }\end{array}$} & 1. Yes, with non traditional institutions \\
\hline & & & 2. Yes, with traditional institutions \\
\hline & & & 3. No, I do not have any \\
\hline & & Have you received & 1. No, I have never received \\
\hline & & $\begin{array}{l}\text { any subsidies from the } \\
\text { government over the past }\end{array}$ & 2. I have received, but currently I do not have any \\
\hline & & five years? & 3. Yes, currently I have \\
\hline & & You use your incomes to... & 1. Pay loans \\
\hline & & & 2. Buy inputs (seeds, fertilisers, and so on \\
\hline & & & 3. Ensure family welfare \\
\hline & & Who makes the decisions & 1. Men \\
\hline & & about how to spend the & 2. Women \\
\hline & & & 3. Shared with all the family \\
\hline & Entrepreneurism & Does someone in your family & 1. No \\
\hline & & belong to a new enterprise to & 2. Currently we do not belong \\
\hline & & & 3. Yes \\
\hline & Land & The high share of your farm & 1. Contrary to the soil type \\
\hline & Characteristics & is used to... & 2. Partly according to the soil type \\
\hline & & & 3. According to the soil type \\
\hline & & Do you think the quality of & 1. Low \\
\hline & & the soil in your farm is... & 2. Medium \\
\hline & & & 3. High \\
\hline & Main Crops & The production in your first & 1. Less than the average \\
\hline & & most important/activity crop & 2. Equal than the average \\
\hline & & is... & 3. Superior to the average \\
\hline & & The production in your & 1. Less than the average \\
\hline & & second most important/ & 2. Equal than the average \\
\hline & & activity crop is... & 3. Superior to the average \\
\hline & & The production in your third & 1. Less than the average \\
\hline & & most important/activity crop & 2. Equal than the average \\
\hline & & is... & 3. Superior to the average \\
\hline
\end{tabular}




\begin{tabular}{|c|c|c|c|}
\hline \multirow{21}{*}{$\begin{array}{l}\text { Economic } \\
\text { Heritage }\end{array}$} & \multirow{12}{*}{$\begin{array}{l}\text { Access to } \\
\text { Markets }\end{array}$} & \multirow{3}{*}{$\begin{array}{l}\text { Where do you sell your } \\
\text { products? }\end{array}$} & 1. To intermediaries \\
\hline & & & 2. In a market close to the farm \\
\hline & & & 3. In the farm \\
\hline & & \multirow{3}{*}{$\begin{array}{l}\text { How do people pay for your } \\
\text { products? }\end{array}$} & 1. Over 60 days \\
\hline & & & 2. 30 days maximum \\
\hline & & & 3. Immediate \\
\hline & & \multirow{3}{*}{$\begin{array}{l}\text { Are the people who buy } \\
\text { the harvest the same that } \\
\text { sell the fertilisers in your } \\
\text { neighbourhood? Monopoly }\end{array}$} & 1. Yes \\
\hline & & & 2. It happened, but nowadays not \\
\hline & & & 3. No \\
\hline & & \multirow{3}{*}{$\begin{array}{l}\text { Do you prefer selling the } \\
\text { harvest altogether with your } \\
\text { neighbours? }\end{array}$} & 1. No \\
\hline & & & 2. Sometimes \\
\hline & & & 3. Yes \\
\hline & \multirow{3}{*}{$\begin{array}{l}\text { Technical } \\
\text { Assistance }\end{array}$} & \multirow{3}{*}{$\begin{array}{l}\text { The quality of the technical } \\
\text { assistance you receive is... }\end{array}$} & 1. Low \\
\hline & & & 2. Medium \\
\hline & & & 3. High \\
\hline & \multirow{6}{*}{$\begin{array}{l}\text { Advantages for } \\
\text { Markets }\end{array}$} & \multirow{3}{*}{$\begin{array}{l}\text { Do you currently harvest any } \\
\text { special products? (Organic, } \\
\text { green label, etc?) }\end{array}$} & 1. No, currently I do not \\
\hline & & & 2. No, I did, but currently I do not \\
\hline & & & 3. Yes, I do \\
\hline & & \multirow{3}{*}{$\begin{array}{l}\text { Do you do some post harvest } \\
\text { management? }\end{array}$} & 1. No, currently I do not \\
\hline & & & 2. No, I did, but currently I do not \\
\hline & & & 3. Yes, I do \\
\hline
\end{tabular}


